\title{
Effects of the addition of small quantities of ceria on the catalytic behavior of Pd-only close-coupled catalysts during automobile exhaust elimination
}

\author{
Xue Yang, Linyan Yang, Siyu Lin, Renxian Zhou* \\ Institute of Catalysis, Zhejiang University, Hangzhou 310028, Zhejiang, China
}

\section{A R T I C L E I N F O}

Article history:

Received 31 March 2014

Accepted 26 April 2014

Published 20 August 2014

\section{Keywords:}

Palladium-only close-coupled catalyst

Catalytic behavior

Appropriate ceria

Thermal stability

In situ diffuse reflectance infrared

Fourier transform spectroscopy

\begin{abstract}
A B S T R A C T
A series of $\mathrm{La}-\mathrm{Al}_{2} \mathrm{O}_{3}$ supported Pd-Ce close-coupled catalysts were synthesized by a co-adsorption impregnation method and subsequently investigated. In the case of fresh catalysts, the presence of an optimal concentration of ceria obviously promoted the catalytic activity during $\mathrm{HC}$ and $\mathrm{NO}_{x}$ eliminations, owing to the interaction between the palladium oxide species $\left(\mathrm{PdO}_{x}\right)$ and $\mathrm{CeO}_{2}$ that improves the oxidation of $\mathrm{Pd}^{0}$ to $\mathrm{PdO}$ and enhances the adsorption of nitrite/nitrates and isocyanate intermediate species on the support under reaction conditions. $\mathrm{Pd}-\mathrm{Ce}(2.0) / \mathrm{La}-\mathrm{Al}_{2} \mathrm{O}_{3}$ catalyst (where 2.0 is the wt $\%$ of $\mathrm{CeO}_{2}$ ) exhibited the highest catalytic activity for $\mathrm{HC}$ and $\mathrm{NO}$ eliminations. Following aging at $1100{ }^{\circ} \mathrm{C}$, the operational window for $\mathrm{HC}$ and $\mathrm{NO}_{x}$ conversions was broadened and the thermal stability of the catalysts was also improved as a result of the presence of an appropriate quantity of ceria (2.0-4.0 wt\%). The enhanced interactions between $\mathrm{PdO}_{x}$ and $\mathrm{CeO}_{2}$ evidently led to the formation of a Pd-O-Ce system, stabilizing $\mathrm{PdO}_{x}$ species with smaller particle sizes at high temperatures. This result is significant since it suggests a means of improving the catalytic performance of Pd-only close-coupled catalysts during automobile exhaust elimination.
\end{abstract}

(C) 2014, Dalian Institute of Chemical Physics, Chinese Academy of Sciences. Published by Elsevier B.V. All rights reserved.

\section{Introduction}

Because of the growing concerns regarding pollution from vehicle exhaust, emissions regulations worldwide are becoming increasingly strict. Three-way catalytic converters (TWC) are currently the primary technology used to control the various regulated compounds emitted by cars [1] and TWC formulations containing $\mathrm{Pt} / \mathrm{Rh}, \mathrm{Pt} / \mathrm{Pd} / \mathrm{Rh}, \mathrm{Pd} / \mathrm{Rh}$ and $\mathrm{Pd}$-only noble metal combinations are all in commercial use [2]. However, Pd-only TWCs have received considerable attention for automotive emissions catalytic conversion and the number of vehicles equipped with Pd-only TWCs is increasing on the basis of the remarkable activity of these systems during oxidation reac- tions, as well as the availability of cleaner fuels and economic aspects [3]. It has long been recognized that $80 \%-90 \%$ of the hydrocarbon (HC) emissions from automobiles occur during cold-start conditions. Thus, a typical vehicle may fail stringent emission standards if the HC emissions from cold-start are not controlled [4]. Several potential solutions have been proposed to the cold-start problem, including HC traps, electrically heated catalysts, combustion heated catalysts, exhaust-gas ignition, microwave heating and close-coupled catalysts [5]. Among those solutions, close-coupled catalysts are the most direct and efficient, as no additional equipment or power inputs are needed. In such systems, the close-coupled catalyst is positioned close to the engine to allow for a rapid increase in the

\footnotetext{
* Corresponding author. Tel: +86-571-88273290; Fax: +86-571-88273283; E-mail: zhourenxian@zju.edu.cn

This work was supported by the National High Technology Research and Development Program of China (863 Program, 2011AA03A406) and Zhejiang Leading Team of Science and Technology Innovation (2009R50020).

DOI: 10.1016/S1872-2067(14)60157-1 | http://www.sciencedirect.com/science/journal/18722067 | Chin. J. Catal., Vol. 35, No. 8, August 2014
} 
catalyst temperature. Unfortunately, the temperature in a close-coupled catalytic converter can reach in excess of $1000^{\circ} \mathrm{C}$ during the practical application of the three-way catalytic conversion process, resulting in deactivation of Pd-based catalysts either through loss of the active surface by sintering or by transformation of the Pd to the metallic state [6].

Ce has traditionally been employed as a promoter [7-9] or as a support [10-12] and is well known as an excellent oxygen storage material because of its combination of facile redox cycling between the $\mathrm{Ce}^{3+}$ and $\mathrm{Ce}^{4+}$ oxidation states, good thermal stability, compatibility with noble metals and ease of insertion into alumina [2]. In addition, the ability of ceria to stabilize Pd in a highly dispersed state is well recognized, since the insertion of Pd into the cerium oxide lattice forms stable Pd-O-Ce bonds and thus leads to a high degree of dispersion [13]. Moreover, Ce can disperse on an alumina support in the form of two-dimensional regions when present at $\leq 10 \%$ by weight [14], thus serving as a bridge to connect $\mathrm{Pd}$ and $\mathrm{Al}_{2} \mathrm{O}_{3}$. Additionally, a strong interaction between $\mathrm{CeO}_{2}$ and $\mathrm{Al}_{2} \mathrm{O}_{3}$ under oxidizing conditions leads to the formation of $\mathrm{CeAlO}_{3}$ at the interface, which helps to stabilize the surface area of the $\mathrm{Al}_{2} \mathrm{O}_{3}$ $[15,16]$, although overly large concentrations of Ce will encapsulate the metal nanoparticles, resulting in an irreversible loss of the metal's active sites [17]. We therefore chose to use Ce and to synthesize Pd-Ce nanoparticles supported on modified $\mathrm{Al}_{2} \mathrm{O}_{3}$, employing low ceria concentrations ranging from 0 to 4.0 $\mathrm{wt} \%$, in an attempt to determine the optimal ceria concentration.

Cargnello et al. $[6,18,19]$ exploited the preorganization of variably functionalized thiol-protected Pd nanoparticles (with either 11-mercaptoundecanoic acid, 9-mercapto-1-nonanol or 1-dodecanethiol) and Ce(IV) alkoxide to form $\mathrm{Pd@CeO}$ nanoparticles. This method, however, is not suitable for commercial applications, since the structure of $\mathrm{Pd} @ \mathrm{CeO}_{2}$ is unstable at high temperatures. Wang et al. [20] prepared Pd-Ce catalysts by a stepwise impregnation method, in which the supports are first impregnated using $\mathrm{PdCl}_{2}$ acidic aqueous solutions, after which they are calcined at $500{ }^{\circ} \mathrm{C}$ and then impregnated with a $\mathrm{Ce}\left(\mathrm{NO}_{3}\right)_{3}$ aqueous solution using the same method. In this method, Ce is not introduced within the first step. In our work, we employed a co-adsorption impregnation method to form a Pd-Ce system, in which the Pd is initially combined with the cerium oxide. A series of Pd-Ce close-coupled catalysts with varying $\mathrm{CeO}_{2}$ contents were produced in this manner and have been characterized by means of three-way catalytic activity measurements, CO adsorption, high revolution transmission electron microscopy, hydrogen temperature programmed reduction and in situ DRIFTS. These techniques are all useful means of gaining insight into potentially important parameters involving the configuration of $\mathrm{PdO}_{x}$ particles on the surface of the support and the interaction of $\mathrm{PdO}_{x}$ with $\mathrm{CeO}_{2}$, which may be responsible for enhancing the catalytic performance of TWCs.

\section{Experimental}

\subsection{Catalyst preparation}

The La-modified $\mathrm{Al}_{2} \mathrm{O}_{3}$ support was purchased from the Rhodia Company. Pd-Ce close-coupled catalysts were prepared by a co-adsorption impregnation method at $25^{\circ} \mathrm{C}$, with a theoretical $\mathrm{Pd}$ content of $1 \mathrm{wt} \%$. In this process, aqueous $\mathrm{Pd}\left(\mathrm{NO}_{3}\right)_{2}$ and $\mathrm{Ce}\left(\mathrm{NO}_{3}\right)_{3}$ solutions were initially mixed for 20 min (applying $\mathrm{CeO}_{2}$ contents of $0,0.25,0.5,1.0,2.0$ and 4.0 wt\%), following which the appropriate mass of La-modified $\mathrm{Al}_{2} \mathrm{O}_{3}$ was quickly added to the solution. After the mixture was stirred overnight, the powder was dried at $110{ }^{\circ} \mathrm{C}$ and then calcined at $500{ }^{\circ} \mathrm{C}$ for $2 \mathrm{~h}$ in static air. The resulting catalysts were termed $\mathrm{Pd} / \mathrm{La}-\mathrm{A}$ and Pd-Ce $(x) /$ La-A (where $x=0.25,0.5,1.0,2.0$ and 4.0). A portion of each catalyst was further aged at $1100{ }^{\circ} \mathrm{C}$ for $4 \mathrm{~h}$ in static air to investigate the thermal stability of the samples, and these aged specimens were denoted as Pd/La-A-a and Pd-Ce $(x) /$ La-A-a $(x=0.25,0.5,1.0,2.0$ and 4.0).

\subsection{Catalytic activity tests}

The catalytic activity tests were performed with a Bruker EQ55 FTIR spectrometer coupled with a multiple reflection transmission cell (Infrared Analysis, Inc.) before and after the simulated exhaust gas passed through the reactor. $0.2 \mathrm{ml}$ catalyst was held in a quartz tube in the fixed-bed quartz reactor by packing quartz wool at both ends of the tube. The feed stream was regulated using special mass flow controllers and was composed of $0.12 \%$ NO, $0.03 \% \mathrm{NO}_{2}, 0.066 \% \mathrm{C}_{3} \mathrm{H}_{6}, 0.033 \%$ $\mathrm{C}_{3} \mathrm{H}_{8}, 0.6 \% \mathrm{CO}$ and $0.745 \% \mathrm{O}_{2}$ with the balance $\mathrm{Ar}$, at a GHSV of $43000 \mathrm{~h}^{-1}$ relative to the catalyst volume and the gas flow rate at room temperature $\left(25^{\circ} \mathrm{C}\right)$. Although a small quantity of $\mathrm{H}_{2} \mathrm{O}$ was generated in the three-way catalytic reaction in our study, its presence would cause serious damage to the FTIR spectrometer and therefore $\mathrm{H}_{2} \mathrm{O}$ was removed from the product stream before the gas passed through the multiple reflection transmission cell, and thus its concentration is not provided in the tabulation of results.

The air/fuel ratio $(\lambda)$ was defined as equal to $\left(2 V_{02}+V_{\mathrm{NO}}+\right.$ $\left.2 V_{\mathrm{NO} 2}\right) /\left(V_{\mathrm{CO}}+9 V_{\mathrm{C} 3 \mathrm{H} 6}+10 V_{\mathrm{C} 3 \mathrm{H} 8}\right)$, where $V$ is the concentration of each gas in units of volume percent, and a $\lambda$ value of one was used in all the activity measurements. The operational window trials were carried out at $400{ }^{\circ} \mathrm{C}$, applying different $\lambda$ values by adjusting the concentration of $\mathrm{O}_{2}$.

\subsection{Characterization techniques}

$\mathrm{H}_{2}$-TPR measurements were carried out on a GC-1690 chromatograph to observe the reducibility of the catalysts. During these tests, $50 \mathrm{mg}$ catalyst was pretreated at $200{ }^{\circ} \mathrm{C}$ in $\mathrm{N}_{2}(30 \mathrm{ml} / \mathrm{min})$ for $0.5 \mathrm{~h}$ and then cooled to $-90{ }^{\circ} \mathrm{C}$ with liquid nitrogen. The reducing gas ( $5 \mathrm{vol} \% \mathrm{H}_{2} / \mathrm{Ar}$ at $40 \mathrm{ml} / \mathrm{min}$ ) was passed through the sample and the temperature was raised to $900{ }^{\circ} \mathrm{C}$ at a rate of $10{ }^{\circ} \mathrm{C} / \mathrm{min}$. The consumption of hydrogen during the reduction was measured by a thermal conductivity detector (TCD).

Pd dispersion and particle sizes were determined by CO chemisorption at room temperature, using a CHEMBET-3000 (Quantachrome Co.). Prior to the experimental trials, each sample was reduced under a flow of $5 \% \mathrm{H}_{2} / 95 \% \mathrm{~N}_{2}$ at $400{ }^{\circ} \mathrm{C}$ 
for $1 \mathrm{~h}$ and then purged with He at the same temperature for $0.5 \mathrm{~h}$. The sample was subsequently cooled to room temperature under an He flow and maintained at this temperature for another $0.5 \mathrm{~h}$. Finally, CO pulses were injected into the sample bed every 5 min until no further consumption of CO could be detected. The Pd dispersion (D) was calculated using the following equation [21]:

$$
D(\%)=100 \times\left[(V \mathrm{co} \times f) /\left(C_{\mathrm{Pd}} \times m_{\text {Cat. }} \times 22414\right)\right] \times m
$$

Here Vco is the CO volume adsorbed $(\mathrm{mL}), f$ is the stoichiometric factor, $C_{\mathrm{Pd}}$ is the $\mathrm{Pd}$ metal content (wt\%), and $m_{\text {Cat. }}$ is the catalyst weight $(\mathrm{g})$. The $\mathrm{Pd}$ particle size $(d)$ was calculated according to the following equation:

$$
d(\mathrm{~nm})=6 \times 10^{5} \times \mathrm{M}_{\mathrm{Pd}} /\left(\rho_{\mathrm{Pd}} \times D \times S_{\mathrm{Pd}}\right)
$$

Here $M_{\mathrm{Pd}}$ is the molar mass of $\mathrm{Pd}(106.42 \mathrm{~g} / \mathrm{mol}), \rho_{\mathrm{Pd}}$ is the $\mathrm{Pd}$ density $\left(12 \mathrm{~g} / \mathrm{cm}^{3}\right)$, and $S_{\mathrm{Pd}}$ is the molar surface area of Pd assuming equidistribution of the low index faces $(S=47780$ $\mathrm{m}^{2} / \mathrm{mol}$ for Pd metal).

HRTEM images were obtained using a TECNAI G220 instrument operating at $200 \mathrm{kV}$ with a perforated carbon film supported on a copper grid. Catalysts were crushed in an agate mortar and then ultrasonically dispersed in ethanol. EDS analysis was used to record elemental maps of samples, thus determining the chemical compositions of the catalysts.

Diffuse reflectance infrared Fourier transform spectroscopy (DRIFTS) analyses were performed with a Nicolet 6700 FTIR spectrometer equipped with an MCT detector, a DRIFTS cell fitted with $\mathrm{CaF}_{2}$ windows and a heated reaction chamber for high-temperature trials. Spectra were collected by averaging 32 scans at a resolution of $4 \mathrm{~cm}^{-1}$. Prior to analysis, catalysts were pretreated in Ar at $450{ }^{\circ} \mathrm{C}$ for $0.5 \mathrm{~h}$ and then cooled to $30{ }^{\circ} \mathrm{C}$. The composition and flow rate of the feed stream were kept constant through each test.

\section{Results and discussion}

\subsection{Catalytic performances}

Fig. 1 presents the conversions of $\mathrm{HC}, \mathrm{CO}, \mathrm{NO}$ and $\mathrm{NO}_{2}$ under stoichiometric $\mathrm{CO}+\mathrm{HC}+\mathrm{NO}_{x}+\mathrm{O}_{2}$ reaction conditions $(\lambda=1)$ over fresh $\mathrm{Pd} / \mathrm{La}-\mathrm{A}$ and $\mathrm{Pd}-\mathrm{Ce}(x) / \mathrm{La}-\mathrm{A}$ catalysts. Over the temperature range from 150 to $200{ }^{\circ} \mathrm{C}, \mathrm{HC}$ and $\mathrm{NO}$ did not take part in the reaction, while the reactions $\mathrm{CO}+1 / 2 \mathrm{O}_{2} \rightarrow \mathrm{CO}_{2}$ and $2 \mathrm{NO}_{2}$ $+4 \mathrm{CO} \rightarrow \mathrm{N}_{2}+4 \mathrm{CO}_{2}$ predominated. The light-off temperatures associated with $\mathrm{CO}$ and $\mathrm{NO}_{2}$ conversions increased with increasing $\mathrm{CeO}_{2}$ content, indicating that the addition of $\mathrm{CeO}_{2}$ inhibited the conversion of $\mathrm{CO}$ and $\mathrm{NO}_{2}$ when the temperature was below $200{ }^{\circ} \mathrm{C}$. At $200-250{ }^{\circ} \mathrm{C}$, the $\mathrm{CO} / \mathrm{O}_{2}$ and $\mathrm{NO}_{2} / \mathrm{CO}$ reactions were still predominant, although $\mathrm{NO}_{2}$ conversion over all catalysts decreased as the temperature increased and the $\mathrm{CO}$ conversion increased to $100 \%$, suggesting that the $\mathrm{CO} / \mathrm{O}_{2}$ reaction occurred more rapidly than the $\mathrm{NO}_{2} / \mathrm{CO}$ reaction. In contrast to the catalytic behavior below $200^{\circ} \mathrm{C}$, the conversion of
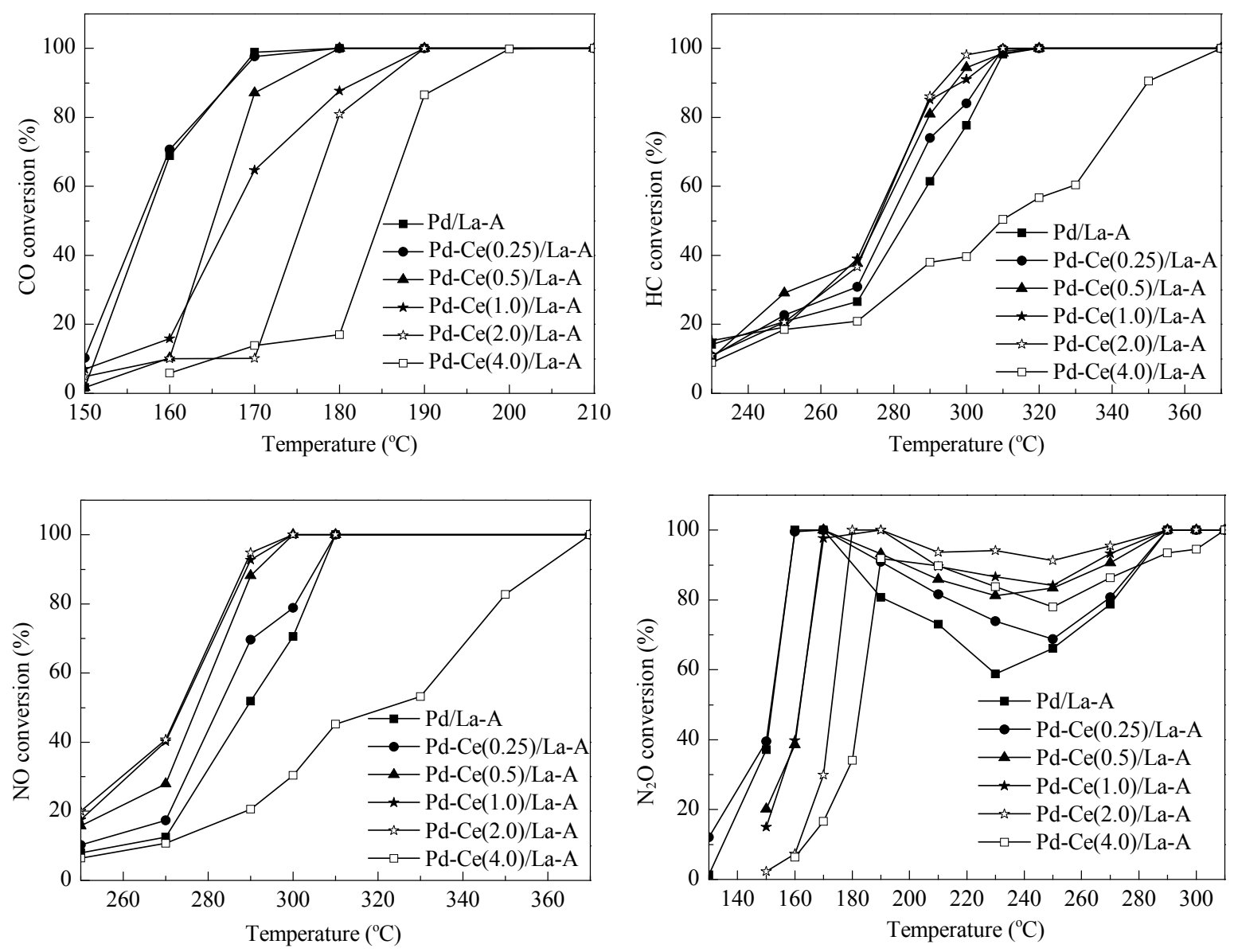

Fig. 1. Three-way conversion as a function of reaction temperature over Pd/La-A and Pd-Ce(x)/La-A catalysts calcined at $500{ }^{\circ} \mathrm{C}$. 
$\mathrm{NO}_{2}$ in the higher temperature range was obviously enhanced with increasing $\mathrm{CeO}_{2}$ content, and Pd-Ce(2.0)/La-A showed the highest activity.

Above $250{ }^{\circ} \mathrm{C}$, the conversion of $\mathrm{HC}$, $\mathrm{NO}$ and $\mathrm{NO}_{2}$ increased as the temperature increased. It can be seen that $\mathrm{HC}$ conversion coincided with $\mathrm{NO}_{x}$ conversion in this range, since $\mathrm{NO}_{x}$ conversion is controlled via the reactions $10 \mathrm{NO}+4 \mathrm{HC} \rightarrow 5 \mathrm{~N}_{2}+4 \mathrm{CO}_{2}+$ $2 \mathrm{H}_{2} \mathrm{O}$ and $10 \mathrm{NO}_{2}+8 \mathrm{HC} \rightarrow 5 \mathrm{~N}_{2}+4 \mathrm{CO}_{2}+4 \mathrm{H}_{2} \mathrm{O}$ [22]. These results show that the presence of an optimum concentration of ceria promotes the catalytic activities associated with $\mathrm{HC}$ and $\mathrm{NO}_{x}$ removal. With increases in the $\mathrm{CeO}_{2}$ content from 0.25 to $2.0 \mathrm{wt} \%$, the catalytic activity first appeared to increase and then sharply decreased at 4.0 wt $\%$ of $\mathrm{CeO}_{2}$ ). Thus, the $\mathrm{Pd}-\mathrm{Ce}(2.0)$ /La-A catalyst was also seen to exhibit better activity than the other catalysts.

Fig. 2 presents the conversions of $\mathrm{HC}, \mathrm{CO}, \mathrm{NO}$ and $\mathrm{NO}_{2}$ under stoichiometric $\mathrm{CO}+\mathrm{HC}+\mathrm{NO}_{x}+\mathrm{O}_{2}$ reaction conditions $(\lambda=1)$ over Pd/La-A-a and Pd-Ce $(x) /$ La-A-a catalysts calcined at 1100 ${ }^{\circ} \mathrm{C}$. A large drop in catalytic activity was observed compared with the results obtained with the fresh catalysts (Fig. 1), because of the deteriorated structure and sintering of active components during the high-temperature pre-treatment [23]. In spite of this, the catalytic activity of the aged samples was still promoted with increasing $\mathrm{CeO}_{2}$ content. Pd-Ce(4.0)/La-A-a exhibited the best catalytic activity for $\mathrm{CO}$ and $\mathrm{HC}$ oxidation while Pd-Ce(2.0)/La-A-a showed the best catalytic activity for
$\mathrm{NO}$ and $\mathrm{NO}_{2}$ elimination. The results indicate that addition of the appropriate amount of $\mathrm{CeO}_{2}$ promotes the thermal stability of the catalysts, and does not suggest any encapsulation of $\mathrm{PdO}_{x}$ species by ceria during the high-temperature pre-treatment, which could have important consequences in terms of improving the catalytic performance of close-coupled catalysts in automobile exhaust elimination.

In our experimental trials, we also evaluated the conversions of $\mathrm{CO}, \mathrm{HC}$ and $\mathrm{NO}_{x}$ under different air/fuel ratios $(\lambda)$ at $400{ }^{\circ} \mathrm{C}$ over fresh and aged catalysts. When using the fresh catalysts (data not shown here), there were no significant differences in the conversions of $\mathrm{CO}, \mathrm{HC}$ and $\mathrm{NO}_{x}$; the $\mathrm{HC}$ conversion remained at $100 \%$ and the $\mathrm{CO}$ conversion was above $80 \%$ over the entire range of $\lambda$ values. Moreover, the $\mathrm{NO}_{x}$ conversions only showed very slight differences from one another. However, the catalytic behavior did exhibit a noticeable change after the catalysts were aged at $1100{ }^{\circ} \mathrm{C}$. As shown in Fig. 3, the conversion of $\mathrm{CO}$ dropped slightly with increasing ceria content under $\lambda<1$ (lean oxygen) conditions. The HC conversion over $\mathrm{Pd} /$ La-A-a was also lower than $80 \%$ even at $\lambda>1$ (rich oxygen) conditions, which may indicate a decrease in the catalytic activity for $\mathrm{HC}$ oxidation due to the reduction of $\mathrm{PdO}$ to $\mathrm{Pd}^{0}$ under the reaction conditions [24]. The $\mathrm{NO}_{x}$ conversion also dropped sharply when the $\lambda$ value was above 0.95 , demonstrating that the operational window of the Pd/La-A-a catalyst was significantly reduced after aging at $1100{ }^{\circ} \mathrm{C}$. However, the operational
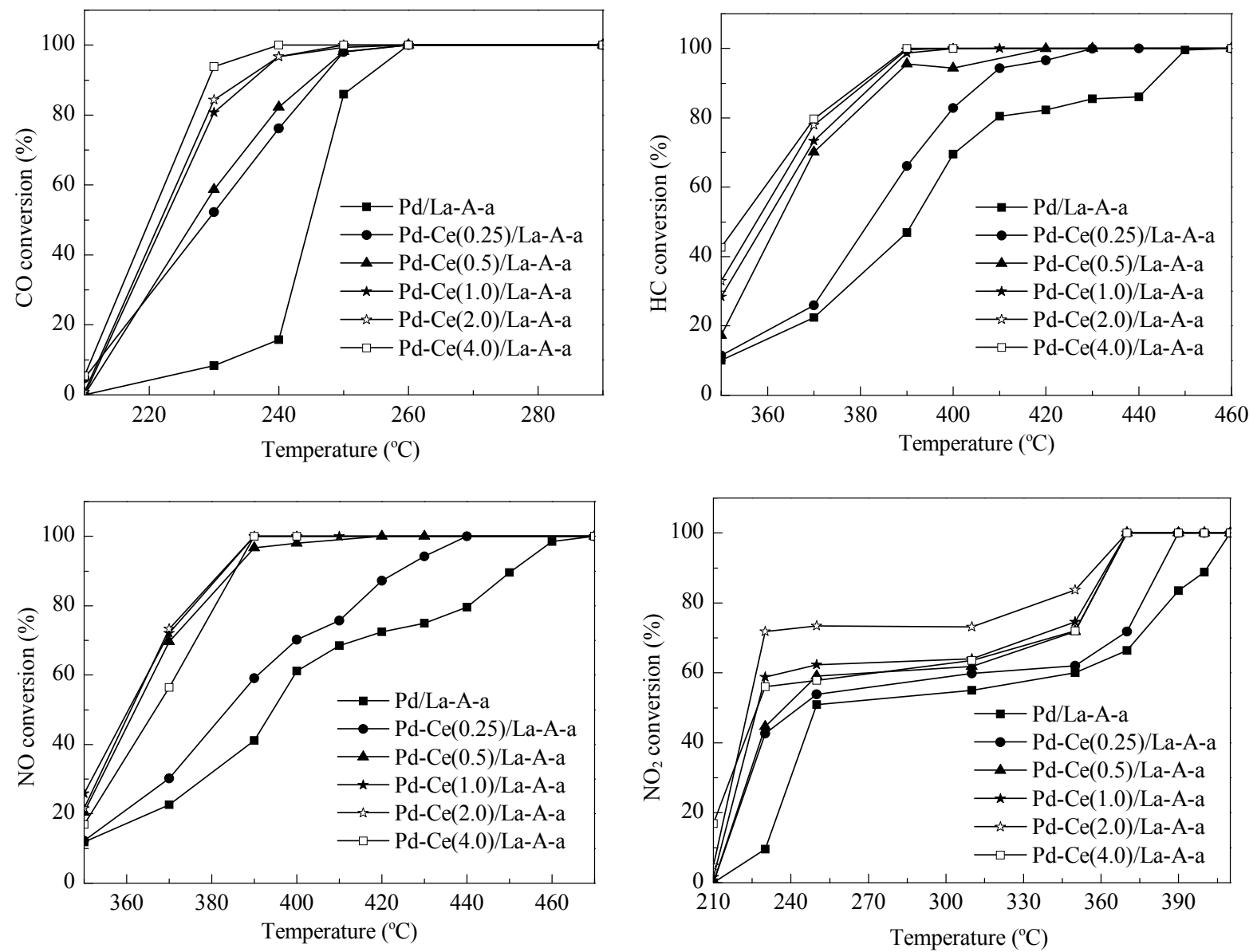

Fig. 2. Three-way conversion as a function of reaction temperature over Pd/La-A-a and Pd-Ce(x)/La-A-a catalysts calcined at $1100{ }^{\circ} \mathrm{C}$. 


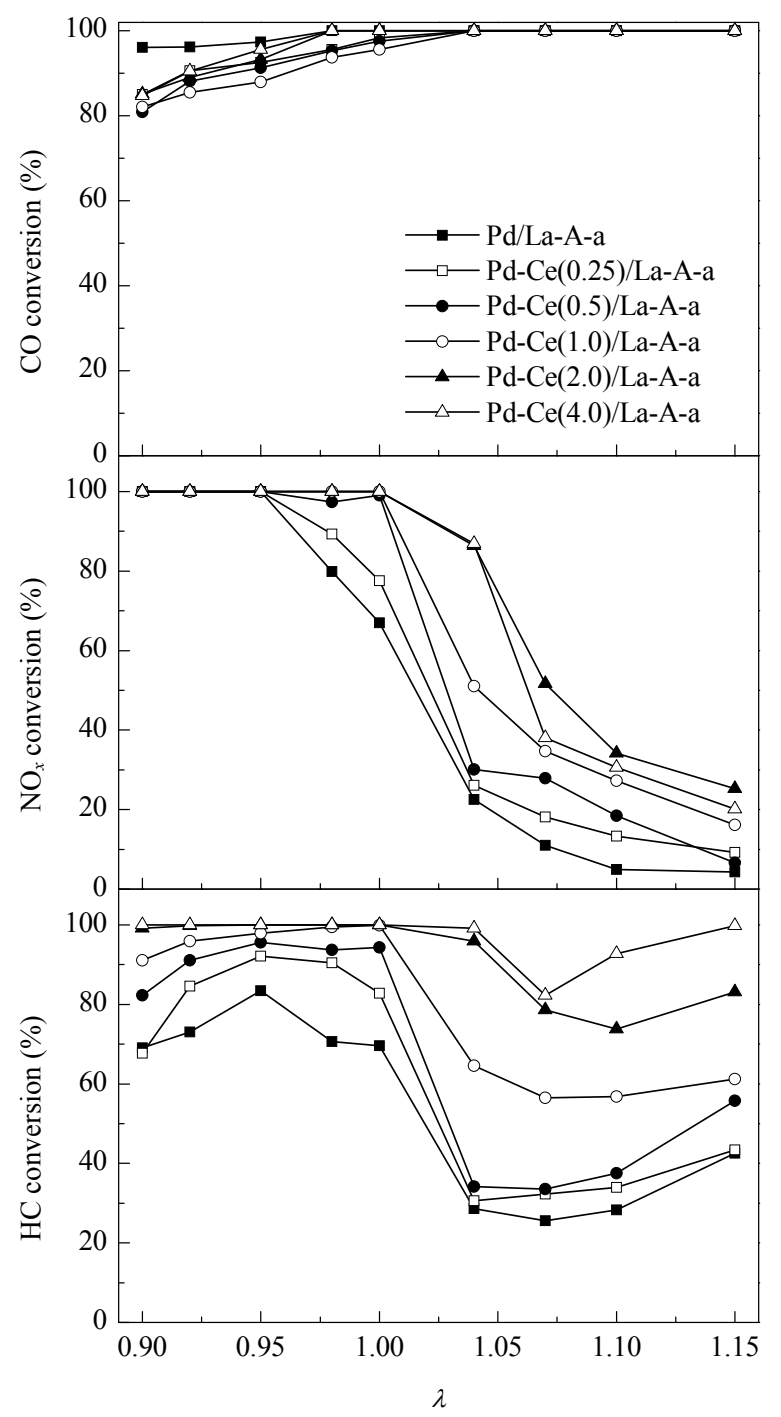

Fig. 3. Conversions as a function of stoichiometric number $(\lambda)$ over $\mathrm{Pd} / \mathrm{La}-\mathrm{A}-\mathrm{a}$ and Pd-Ce $(x) /$ La-A-a catalysts.

window was also broadened by the addition of $\mathrm{CeO}_{2}$, and the conversions of $\mathrm{HC}$ and $\mathrm{NO}_{x}$ both obviously increased with increasing $\mathrm{CeO}_{2}$ content, indicating that the presence of $\mathrm{CeO}_{2}$ stabilizes $\mathrm{PdO}_{x}$ species in oxidized form because of the interaction between $\mathrm{PdO}_{x}$ and $\mathrm{CeO}_{2}$. Pd-Ce(4.0)/La-A-a showed the widest operational window for $\mathrm{HC}$ conversion while $\mathrm{Pd}-\mathrm{Ce}(2.0)$ /La-A-a exhibited the best catalytic behavior for $\mathrm{NO}_{x}$ elimination. To obtain more information about the configuration of $\mathrm{PdO}_{x}$ particles on the surface of the support and the interactions between $\mathrm{PdO}_{x}$ and $\mathrm{CeO}_{2}, \mathrm{CO}$ adsorption, HRTEM, $\mathrm{H}_{2}$-TPR and in situ DRIFTS results obtained for the catalysts are analyzed below.

\section{2. $\quad$ Structural properties}

Pd dispersion and particle size results are presented in Table 1 . For each fresh catalyst, Pd was well dispersed on the support and the calculated Pd particle sizes for these samples exhibited a slight increase with increasing $\mathrm{CeO}_{2}$ contents. In contrast, the Pd particle sizes of the aged catalysts showed significant decreases as the $\mathrm{CeO}_{2}$ content increased, demonstrating that the addition of $\mathrm{CeO}_{2}$ enhances the stability of $\mathrm{PdO}_{x}$ species at high temperatures and helps to slow the sintering progress. The catalyst with a $\mathrm{CeO}_{2}$ content of $2.0 \mathrm{wt} \%$ exhibited the highest $\mathrm{Pd}$ dispersion and smallest Pd particle size after being calcined at $1100{ }^{\circ} \mathrm{C}$, results that are reflected in its catalytic performance.

Table 1 lists the calculated particle sizes of the metal Pd based on theoretical values, which will be somewhat different from the actual sizes of the $\mathrm{PdO}_{x}$ species in the catalysts. To further investigate the structural differences between $\mathrm{Pd} / \mathrm{La}-\mathrm{A}$ and Pd-Ce(2.0)/La-A on the atomic scale, the materials were further studied by TEM, and micrographs of the fresh samples are shown in Fig. 4. Only $\mathrm{La}_{2} \mathrm{O}_{3}$ and $\mathrm{CeO}_{2}$ are observed in these samples, with interplanar distances of 0.307 and $0.312 \mathrm{~nm}$, respectively. No $\mathrm{PdO}_{x}$ particles were found because of the low concentration and high dispersion of this species, and since the small Pd clusters are difficult to distinguish from the support. However, as demonstrated by Fig. 4(c) and Fig. 4(d), X-ray energy dispersive spectroscopy (EDS) line profile analysis confirmed that the bright spots in these images were composed of $\mathrm{Pd}$ and $\mathrm{Ce}$, which clearly establishes the existence of a Pd-Ce structure in the Pd-Ce(2.0)/La-A catalyst.

The micrographs of aged samples are shown in Fig. 5. In Fig. 5(d), lattice fringes with interplanar spacings of 0.262 and $0.298 \mathrm{~nm}$ were determined to be associated with the (101) facet of $\mathrm{PdO}$ and the (011) facet of $\mathrm{Ce}_{2} \mathrm{O}_{3}$. As shown in Fig. 5(a) and Fig. 5(c), the PdO particle sizes exhibited growth after aging at $1100{ }^{\circ} \mathrm{C}$ because of significant agglomeration. It is obvious that the Pd-Ce(2.0)/La-A-a catalyst showed much smaller diameters for its Pd-Ce mixed oxides (20-50 nm) compared with the diameters of the $\mathrm{PdO}_{x}$ species in the Pd/La-A-a (70 $\mathrm{nm})$. These results are consistent with the data presented in

Table 1

Pd dispersion and particle sizes.

\begin{tabular}{lccc|cccc}
\hline Catalyst & $n_{\mathrm{CO}^{\mathrm{a}}}(\mu \mathrm{mol} / \mathrm{g})$ & $D^{\mathrm{b}}(\%)$ & $d^{\mathrm{c}}(\mathrm{nm})$ & Catalyst & $n_{\mathrm{CO}^{\mathrm{a}}}(\mu \mathrm{mol} / \mathrm{g})$ & $D^{\mathrm{b}}(\%)$ & $d^{\mathrm{c}}(\mathrm{nm})$ \\
\hline Pd/La-A & 24.06 & 25.60 & 4.4 & Pd/La-A-a & 1.35 & 1.44 \\
Pd-Ce(0.25)/La-A & 23.99 & 25.53 & 4.4 & Pd-Ce(0.25)/La-A-a & 1.97 & 2.10 \\
Pd-Ce(0.5)/La-A & 26.78 & 28.50 & 3.9 & Pd-Ce(0.5)/La-A-a & 2.52 & 2.68 \\
Pd-Ce(1.0)/La-A & 23.13 & 24.62 & 4.5 & Pd-Ce(1.0)/La-A-a & 2.51 & 41.0 \\
Pd-Ce(2.0)/La-A & 15.68 & 16.68 & 6.7 & Pd-Ce(2.0)/La-A-a & 2.68 & 2.67 \\
Pd-Ce(4.0)/La-A & 14.13 & 15.04 & 7.4 & Pd-Ce(4.0)/La-A-a & 2.43 & 41.7 \\
\hline
\end{tabular}

a The amount of $\mathrm{CO}$ adsorbed on the Pd surface.

${ }^{\mathrm{b}}$ Calculated assuming the adsorption of one $\mathrm{CO}$ molecule on each Pd atom.

${ }^{\mathrm{c}}$ Calculated using Eq. (2). 

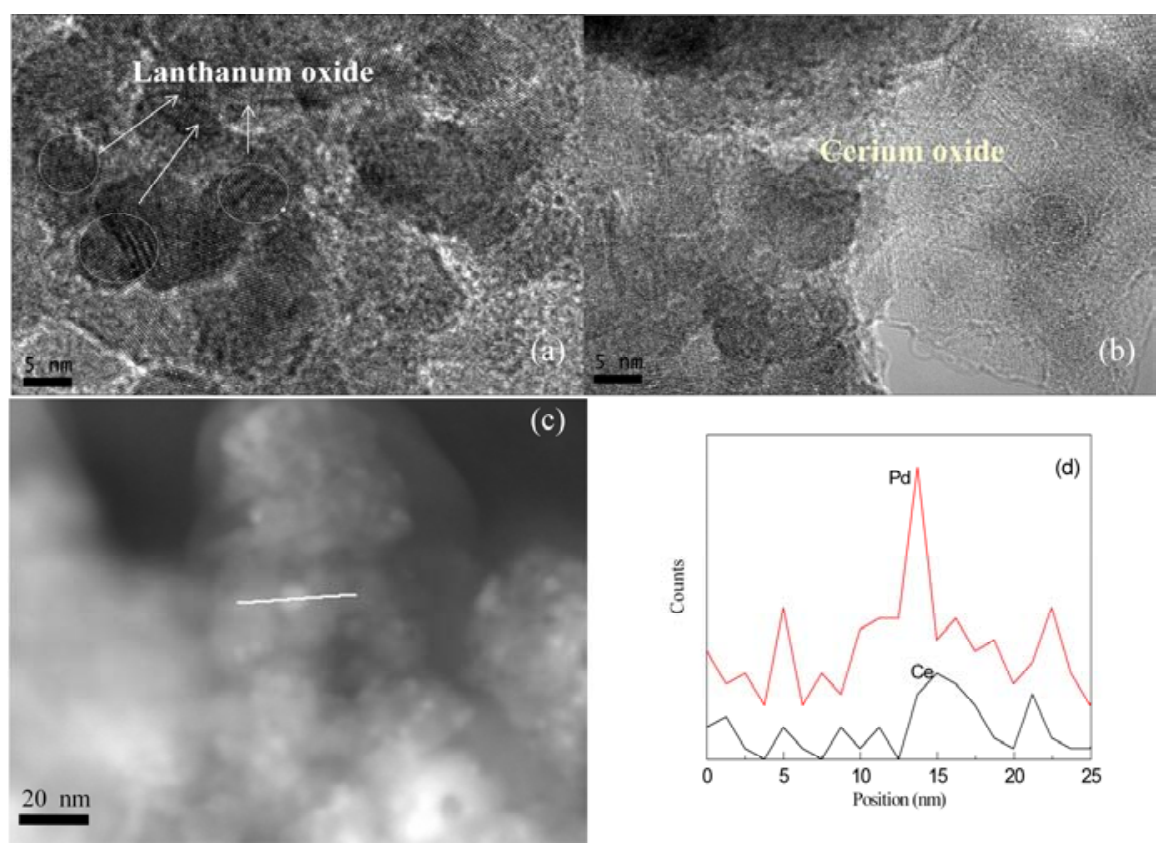

Fig. 4. TEM images of Pd/La-A (a) and Pd-Ce(2.0)/La-A (b) as well as an HAADF-STEM image of Pd-Ce(2.0)/La-A (c) and the corresponding EDS line profile (d).

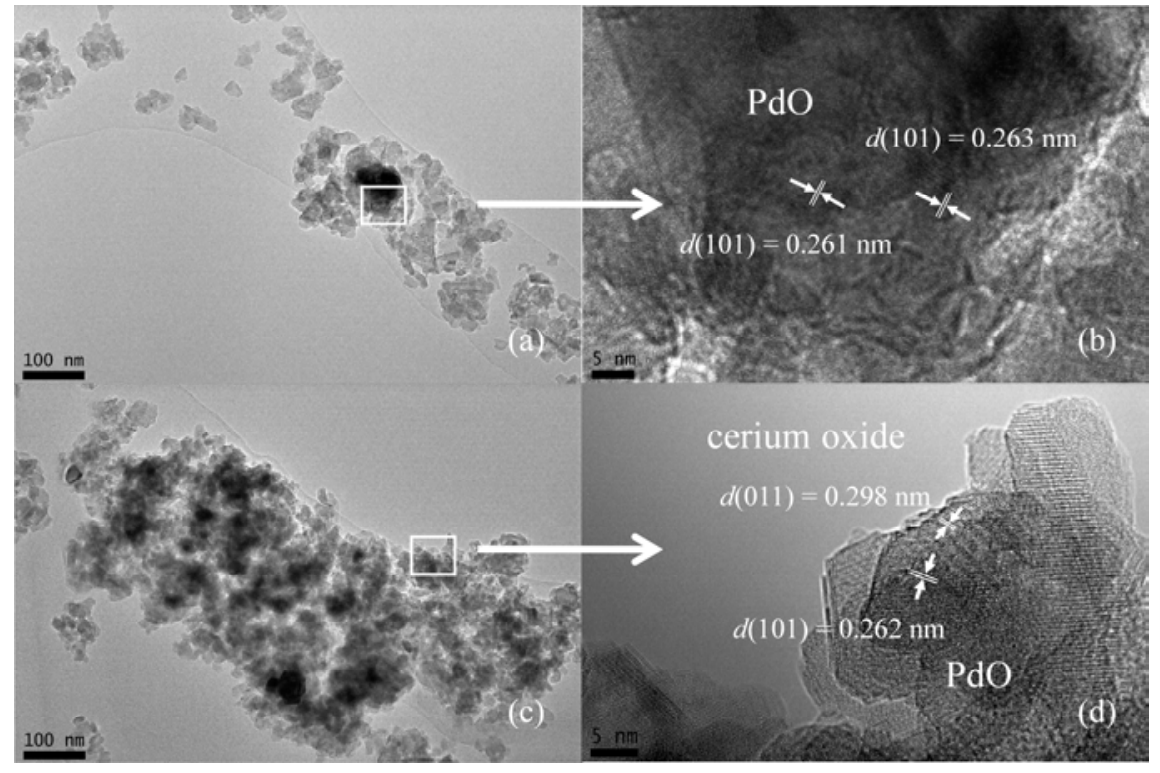

Fig. 5. TEM images of Pd/La-A-a (a, b) and Pd-Ce(2.0)/La-A-a (c, d).

Table 1, establishing that the addition of $\mathrm{CeO}_{2}$ helps to stabilize $\mathrm{PdO}_{x}$ species with smaller particle sizes. This may be the main reason that the Pd-Ce(2.0)/La-A-a catalyst maintained good catalytic performance after the aging treatment.

\section{3. $H_{2}$-TPR results}

Fig. 6 shows the $\mathrm{H}_{2}$-TPR profiles of fresh and aged catalysts. The fresh catalysts exhibit four hydrogen consumption peaks $(\alpha, \beta, \gamma$ and $\delta)$ in addition to a negative peak below $400{ }^{\circ} \mathrm{C}$. According to our previous work [25], peak $\alpha$ is associated with the reduction of $\mathrm{PdO}_{x}$ species finely dispersed on the support, while the negative peak at $70{ }^{\circ} \mathrm{C}$ is generally attributed to the decomposition of palladium hydride when reduced $\mathrm{Pd}$ is ex- posed to $\mathrm{H}_{2}[10,23]$. However, the negative peak disappears when the $\mathrm{CeO}_{2}$ content reaches $0.5 \mathrm{wt} \%$ and peak $\beta$ appears when the $\mathrm{CeO}_{2}$ content further increases. Moreover, peak $\alpha$ undergoes a shift to a slightly higher temperature with increasing $\mathrm{CeO}_{2}$ content. Osorio et al. [26] found that the addition of $\mathrm{Ce}_{x} \mathrm{Zr}_{1-x} \mathrm{O}_{2}$ mixed oxides to $\mathrm{Al}_{2} \mathrm{O}_{3}$ promoted the palladium-support interactions and some hard-to-reduce $\mathrm{PdO}_{x}$ species were formed when $x=0.5$ and 0.33 . Thus we suggest that there is a strong interaction between the metal and $\mathrm{CeO}_{2}$, leading to the catalysts having higher reduction temperatures, such that peak $\beta$ can be attributed to the reduction of $\mathrm{PdO}_{x}$ species undergoing strong interactions with $\mathrm{CeO}_{2}$. Among these catalysts, there were no significant differences in the intensities and temperature locations of peaks $\gamma$ and $\delta$, indicating that these 

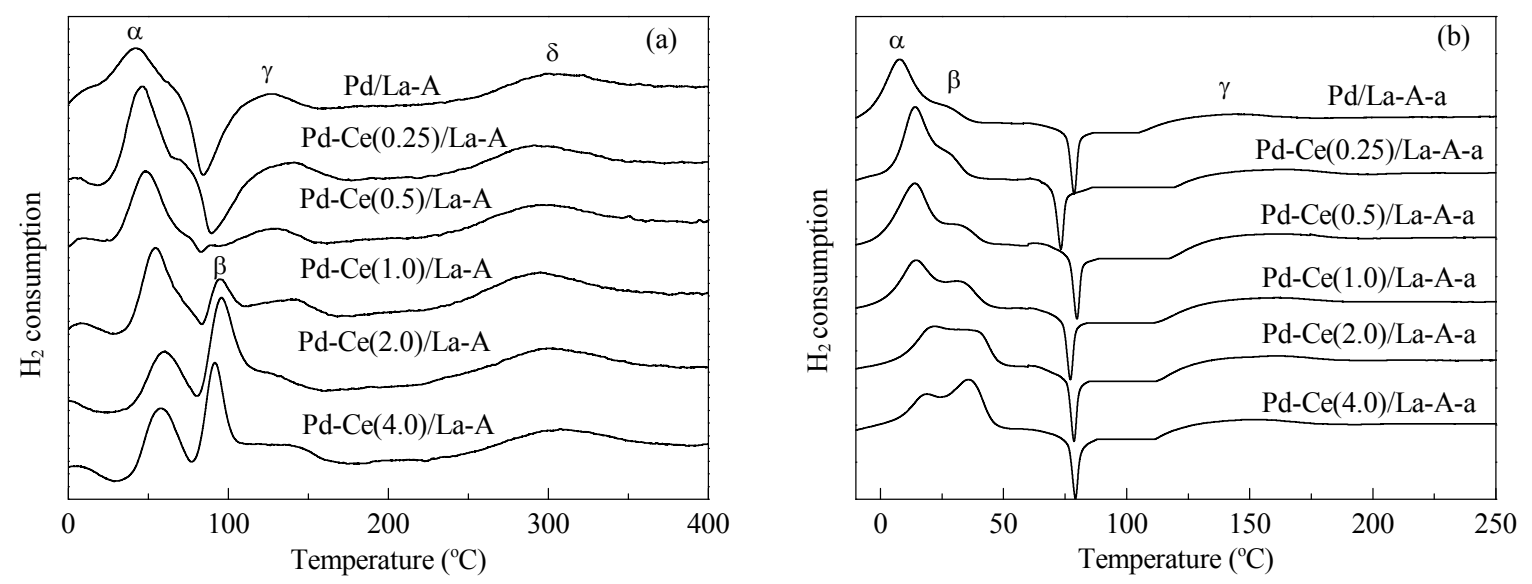

Fig. 6. $\mathrm{H}_{2}$-TPR profiles of fresh (a) and aged catalysts (b).

peaks may be related to the reduction of the La-modified $\mathrm{Al}_{2} \mathrm{O}_{3}$ support. According to the literature [27], contact between Pd and $\mathrm{CeO}_{2}$ particles stabilizes the Pd clusters in an average Pd(I)-like oxidation state, and the presence of such oxidized Pd species serves as a source of oxygen to effectively decrease the light-off temperature during $\mathrm{HC}$ and NO conversions (Fig. 1). Additionally, the enhanced interactions between the $\mathrm{PdO}_{x}$ species and $\mathrm{CeO}_{2}$, indicated by the shifts of both peaks $\alpha$ and $\beta$ to higher temperatures, can be correlated to the decreased catalytic performance during $\mathrm{CO}$ and $\mathrm{NO}_{2}$ conversions at low temperature.

After aging at $1100{ }^{\circ} \mathrm{C}$, the $\mathrm{H}_{2}$ consumption peaks $\alpha$ and $\beta$ both decreased because of reduced dispersion of the active $\mathrm{PdO}_{x}$ species resulting from significant sintering during the aging process. Furthermore, this agglomeration of $\mathrm{PdO}_{x}$ species leads to weakening of the interactions between the $\mathrm{PdO}_{x}$ species and the support, thus shifting both peaks $\alpha$ and $\beta$ to lower temperatures compared with the fresh catalysts. In the case of the aged catalysts, however, peaks $\alpha$ and $\beta$ also shifted to higher temperatures with increasing $\mathrm{CeO}_{2}$ content because of the strong interactions between the $\mathrm{PdO}_{x}$ and $\mathrm{CeO}_{2}$.

\subsection{In situ DRIFTS results}

To assess the potential relationship between the presence of particular Pd phases and catalytic behaviors, in situ DRIFTS studies were performed under different reaction conditions. Fig. 7(a) and Fig. 7(b) present a set of in situ DRIFTS spectra obtained from fresh Pd/La-A and Pd-Ce(2.0)/La-A catalysts under a stoichiometric $\mathrm{CO}+\mathrm{HC}+\mathrm{O}_{2}$ reaction mixture at $250^{\circ} \mathrm{C}$. Bands in the region of $1800-2100 \mathrm{~cm}^{-1}$ can be attributed to carbonyls adsorbed on $\mathrm{Pd}^{0}$ sites. In these spectra, we can observe the presence of on-top-bonded (linear) Pd-CO at 2063 $\mathrm{cm}^{-1}$ and a strong bridge-bonded $\mathrm{Pd}_{2}$-CO peak at $1972 \mathrm{~cm}^{-1}$ along with a three-fold hollow $\mathrm{Pd}_{3}-\mathrm{CO}$ at $1909 \mathrm{~cm}^{-1}[28,29]$, indicating that some $\mathrm{PdO}_{x}$ species are reduced to metallic $\mathrm{Pd}$ under these reaction conditions. However, the intensities of these features in the Pd/La-A spectra are much stronger than those obtained with $\mathrm{Pd}-\mathrm{Ce}(2.0) / \mathrm{La}-\mathrm{A}$, demonstrating that $\mathrm{Pd}-\mathrm{Ce}(2.0) / \mathrm{La}-\mathrm{A}$ retains a large proportion of oxidized Pd spe- cies and thus presenting fewer metallic Pd sites [28]. These results show that the presence of a small amount of $\mathrm{CeO}_{2}$ promotes the reoxidation of $\mathrm{Pd}^{0}$ to $\mathrm{PdO}$ under reaction conditions. Furthermore, there is little evidence of the three-fold hollow $\mathrm{Pd}_{3}$-CO species on the Pd-Ce(2.0)/La-A and the bridge/ on-top-bonded $\mathrm{CO}$ bands are obviously shifted to lower wavenumbers. By analogy with observations reported for $\mathrm{Pd}-\mathrm{Au}$ [30], the formation of Pd-Ce nanoparticles would cause the dilution of $\mathrm{Pd}$ in the $\mathrm{CeO}_{2}$, thus limiting the extent of multi-bonded CO on Pd and further leading to the disappearance of the three-fold hollow $\mathrm{Pd}_{3}$-CO band. The adsorption bands in the range of $1200-1800 \mathrm{~cm}^{-1}$ can be attributed to surface carbonates/carboxylates species adsorbed on $\mathrm{Al}_{2} \mathrm{O}_{3}$ [31,32]. The intensities of these bands do not undergo visible changes over time, indicating that the concentration of carboxylates/carbonates species on the alumina surface is essentially saturated during the initial exposure to the $\mathrm{CO}+\mathrm{HC}+\mathrm{O}_{2}$ reaction mixture because of the complete oxidation of $\mathrm{CO}$ at $250{ }^{\circ} \mathrm{C}$.

Stoichiometric $\mathrm{NO}_{x}$ was abruptly added into the flow after 10 min exposure to a $\mathrm{CO}+\mathrm{HC}+\mathrm{O}_{2}$ mixture at $250{ }^{\circ} \mathrm{C}$ and the corresponding spectra were collected as a function of time. As shown in Fig. 7(c) and (d), bands at 2253 and $2231 \mathrm{~cm}^{-1}$ appear ascribed to isocyanate species adsorbing at octahedral and tetrahedral $\mathrm{Al}^{3+}$ cations, respectively [33]. These NCO species are formed by the interaction of unreacted $\mathrm{CO}$ with adsorbed $\mathrm{N}$ atoms $\left(\mathrm{N}_{\mathrm{a}}\right)$ [34]. Two reaction mechanisms have been proposed for the formation of $\mathrm{N}_{\mathrm{a}}$; the first involves the unimolecular dissociative adsorption of $\mathrm{NO}$ to form $\mathrm{N}_{\mathrm{a}}$ and $\mathrm{O}_{\mathrm{a}}$, while the second involves a direct bimolecular reaction between NO and CO to form $\mathrm{Na}_{\mathrm{a}}$ and $\mathrm{CO}_{2}$ [35]. The significant intensity of the NCO band and its ready detection may be used to roughly determine the onset temperature for NO dissociation, and these bands are observed to reach a maximum after $2 \mathrm{~min}$ and then decrease slightly because of the $\mathrm{NCO}+\mathrm{NO}+\mathrm{O}_{2} \rightarrow \mathrm{N}_{2}$ reaction. However, it is noteworthy that the intensities of the NCO bands on the $\mathrm{Pd}-\mathrm{Ce}(2.0) / \mathrm{La}-\mathrm{A}$ are much stronger than in the Pd/La-A, indicating that more NCO species are formed on the $\mathrm{Pd}-\mathrm{Ce}(2.0) / \mathrm{La}-\mathrm{A}$, and thus this process is responsible for the improved $\mathrm{NO}_{x}$ elimination performance seen for this catalyst at $250{ }^{\circ} \mathrm{C}$, which is in accordance with the catalytic activity data 

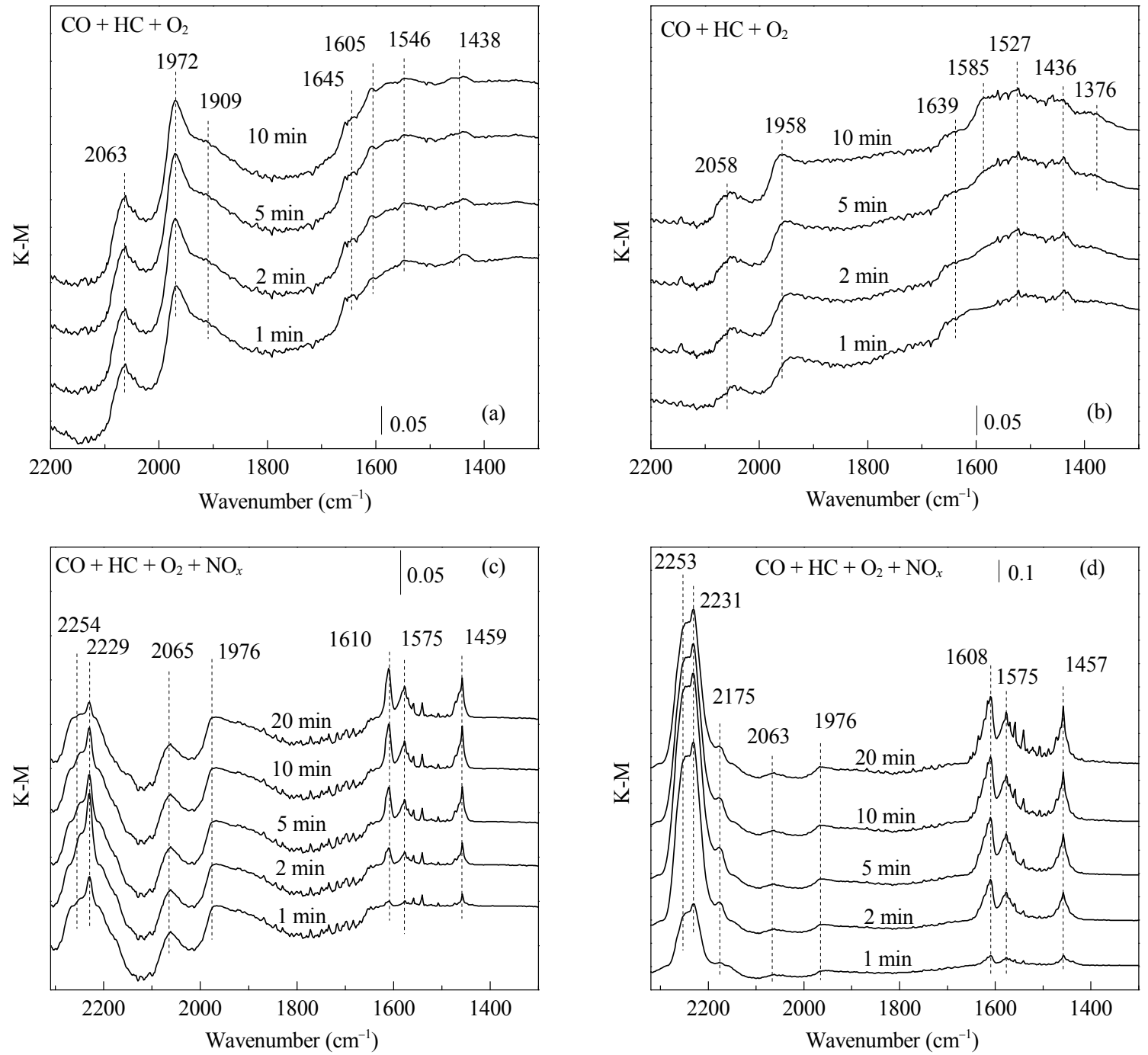

Fig. 7. DRIFTS spectra collected at varying time intervals during exposure of fresh Pd/La-A (a) and Pd-Ce(2.0)/La-A (b) to stoichiometric CO + HC + $\mathrm{O}_{2}$ reaction conditions at $250^{\circ} \mathrm{C}$, and during exposure of Pd/La-A (c) and Pd-Ce(2.0)/La-A (d) to stoichiometric CO $+\mathrm{HC}+\mathrm{O}_{2}+\mathrm{NO}_{x}$ reaction conditions at the same temperature.

shown in Fig. 1. Moreover, it is interesting that a new band is observed at $2175 \mathrm{~cm}^{-1}$ in the Pd-Ce(2.0)/La-A spectra. According to the results of $\mathrm{H}_{2}$-TPR analyses, there are two different $\mathrm{PdO}_{x}$ species dispersed in the catalyst and so this band may be related to $\mathrm{NCO}$ species produced on $\mathrm{Pd}^{0}$ sites having strong interactions with Ce atoms. Under such conditions, NCO species should be able to spill over onto $\mathrm{CeO}_{2}$ sites because of the close contact of the $\mathrm{PdO}_{x}-\mathrm{CeO}_{2}$ particles. Simultaneously, three bands at 1610,1575 and $1459 \mathrm{~cm}^{-1}$ are also observed during the initial exposure to the $\mathrm{CO}+\mathrm{HC}+\mathrm{NO}_{x}+\mathrm{O}_{2}$ mixture, all of which reach a maximum after $5 \mathrm{~min}$ and then remain essentially constant. According to the literature, the band at $1610 \mathrm{~cm}^{-1}$ can be assigned to bidentate nitrates species, while the 1575 and 1459 $\mathrm{cm}^{-1}$ bands may be attributed to acetate species directly related to the reaction between surface nitrates species and HC [36]. The intensities of the nitrate/acetate bands in the Pd-Ce(2.0)/ La-A spectra are also much stronger than those of the bands obtained from $\mathrm{Pd} / \mathrm{La}-\mathrm{A}$, which is related to the superior NO/HC elimination performance of the $\mathrm{Pd}-\mathrm{Ce}(2.0) / \mathrm{La}-\mathrm{A}$ at lower tem- peratures. In addition, compared with Fig. 7(a) and (b), the intensities of the on-top/bridge-bonded $\mathrm{CO}$ species adsorbed on the $\mathrm{Pd}^{0}$ sites are obviously reduced under stoichiometric $\mathrm{CO}$ $+\mathrm{HC}+\mathrm{NO}_{x}+\mathrm{O}_{2}$ reaction conditions, indicating that the presence of strongly oxidizing $\mathrm{NO}_{2}$ species favors the stability of oxidized Pd species under these conditions, especially in the case of small Pd clusters.

To elucidate the reaction mechanism, a set of in situ DRIFTS spectra were obtained for the fresh catalysts under stoichiometric $\mathrm{CO}+\mathrm{NO}_{x}+\mathrm{HC}+\mathrm{O}_{2}$ reaction conditions from 50 to 400 ${ }^{\circ} \mathrm{C}$. As shown in Fig. 8, three bands in the region of 1200-1800 $\mathrm{cm}^{-1}$, assigned to nitrite/nitrates species in a variety of structures/configurations adsorbed on alumina [37,38], can be observed at $50{ }^{\circ} \mathrm{C}$. The intensity of these features over the $\mathrm{Pd}-\mathrm{Ce}(2.0) / \mathrm{La}-\mathrm{A}$ catalyst is much stronger than that over $\mathrm{Pd} /$ La-A and almost reaches an initial maximum at $50{ }^{\circ} \mathrm{C}$, indicating better adsorption on the support after adding $\mathrm{CeO}_{2}$, which may be favorable in terms of improving the NO reduction performance at lower temperatures. These bands decrease 

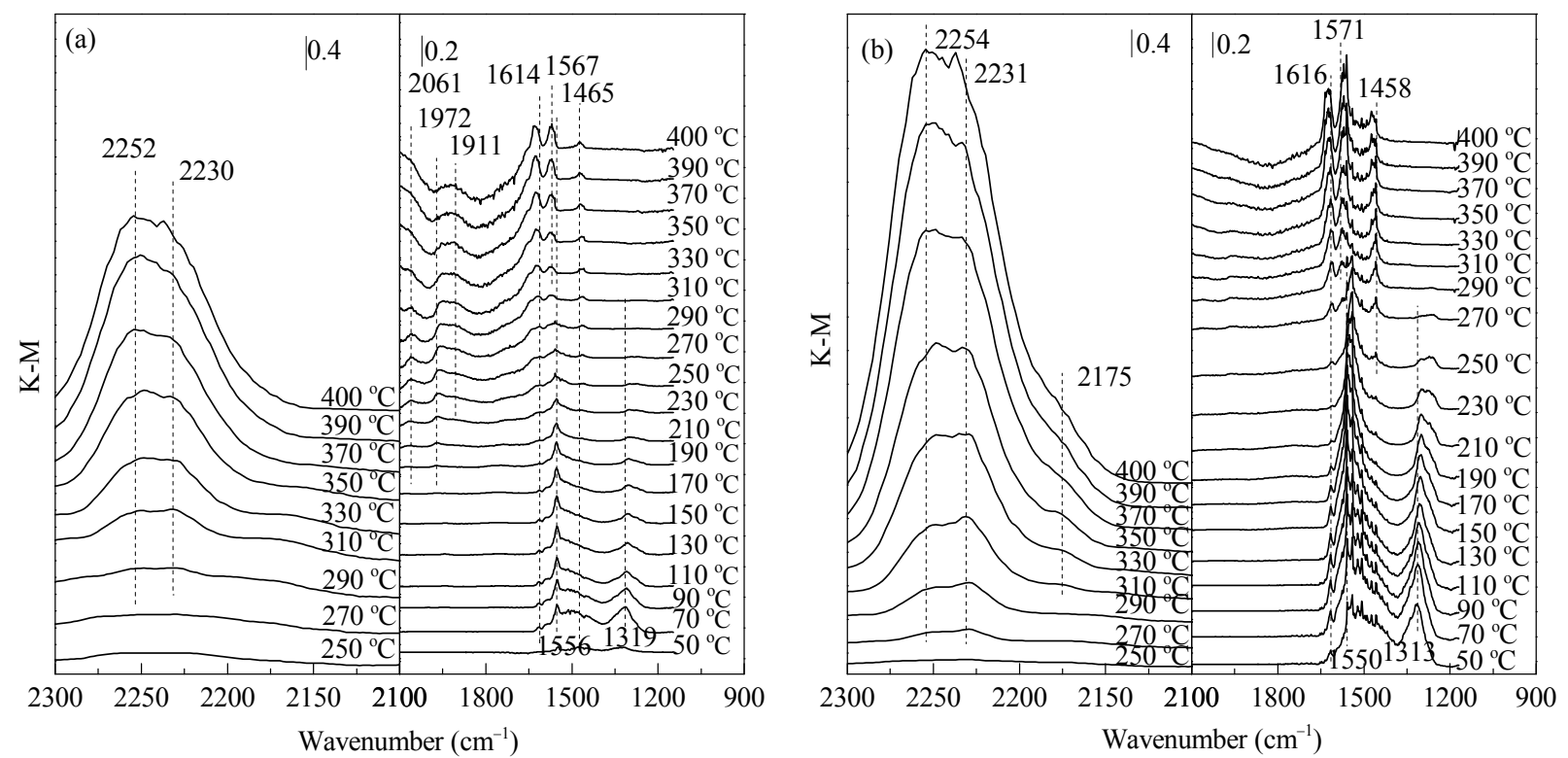

Fig. 8. DRIFTS spectra of Pd/La-A (a) and Pd-Ce(2.0)/La-A (b) catalysts under stoichiometric $\mathrm{CO}+\mathrm{NO}_{x}+\mathrm{HC}+\mathrm{O}_{2}$ conditions from 50 to $400{ }^{\circ} \mathrm{C}$.

in intensity with increasing reaction temperature. The band at $1319 \mathrm{~cm}^{-1}$ assigned to monodentate nitrite species adsorbed on alumina [37] shifts to lower frequencies and disappears at about $270{ }^{\circ} \mathrm{C}$, because of the effect of decreasing $\mathrm{NO}_{x}$ coverage caused by the thermodynamically favored desorption of $\mathrm{NO}_{x}$ and increasing $\mathrm{CO}-\mathrm{NO}_{x}$ reaction activity. Bands in the region of 2100-2300 $\mathrm{cm}^{-1}$, assigned to NCO species, and bands in the region of $1400-1800 \mathrm{~cm}^{-1}$, because of acetate and nitrates species adsorbed on support, also appear and increase in intensity with increasing reaction temperature. As noted, the changes in those bands due to the conversion of $\mathrm{NO}_{x}$ and $\mathrm{HC}$ are in accordance with the observed catalytic performances. The intensities of the nitrate/acetate bands in the Pd-Ce(2.0)/La-A are much stronger than those in the Pd/La-A at the initial lower temperature, suggesting that the $\mathrm{Pd}-\mathrm{Ce}(2.0) / \mathrm{La}-\mathrm{A}$ possesses better $\mathrm{NO} / \mathrm{HC}$ elimination performance at lower temperatures. Moreover, in the case of the Pd/La-A catalyst, bands at 2061, 1972 and $1911 \mathrm{~cm}^{-1}$, all assigned to the adsorption of CO on metallic $\mathrm{Pd}$, begin to appear at $190{ }^{\circ} \mathrm{C}$, indicating that a portion of the $\mathrm{PdO}_{x}$ species is reduced to metallic Pd under these stoichiometric reaction conditions. Also, very weak evidence of these $\mathrm{Pd}^{0}-\mathrm{CO}$ species can be observed in the $\mathrm{Pd}-\mathrm{Ce}(2.0) / \mathrm{La}-\mathrm{A}$ catalyst at higher temperatures, demonstrating the improved stabilization of oxidized $\mathrm{PdO}_{x}$ species on the Pd-Ce catalysts.

\section{Conclusions}

A series of $\mathrm{Pd}-\mathrm{Ce} / \mathrm{La}-\mathrm{Al}_{2} \mathrm{O}_{3}$ close-coupled catalysts were prepared by a co-adsorption impregnation method. In the case of each unaged catalyst, the presence of an appropriate quantity of $\mathrm{CeO}_{2}$ obviously enhanced the catalytic activity during $\mathrm{HC}$ and NO eliminations because of interactions between $\mathrm{PdO}_{x}$ species and $\mathrm{CeO}_{2}$ that improved the ability of $\mathrm{Pd}^{0}$ to reoxidize to PdO and enhanced the adsorption of nitrite/nitrates and isocyanate intermediate species under reaction conditions. The Pd-Ce(2.0)/La-A catalyst exhibited the best catalytic activity for
$\mathrm{HC}$ and $\mathrm{NO}$ eliminations and the addition of $\mathrm{CeO}_{2}$ inhibited the conversions of $\mathrm{CO}$ and $\mathrm{NO}_{2}$. The $\mathrm{Pd}-\mathrm{Ce}(4.0) / \mathrm{La}-\mathrm{A}$ catalyst showed the lowest catalytic activity for $\mathrm{CO}, \mathrm{HC}$ and $\mathrm{NO}_{x}$ eliminations, which may result from encapsulation of $\mathrm{Pd}$ particles by excess $\mathrm{CeO}_{2}$ and associated inhibition of its catalytic performance. However, after aging treatment, the operational window for $\mathrm{HC}$ and $\mathrm{NO}_{x}$ conversions was obviously broadened because of the presence of optimal concentrations of $\mathrm{CeO}_{2}$ (2.0-4.0 wt\%), and the catalytic activities for $\mathrm{CO}, \mathrm{HC}$ and $\mathrm{NO}_{x}$ eliminations were evidently promoted with increased levels of ceria content. These effects demonstrate that the presence of optimal $\mathrm{CeO}_{2}$ concentrations favors stabilization of $\mathrm{PdO}_{x}$ species with smaller particle sizes because of the strong interactions between such $\mathrm{PdO}_{x}$ species and $\mathrm{CeO}_{2}$.

\section{References}

[1] Zhao B, Wang Q Y, Ge C H, Li G F, Zhou R X. Chin J Catal (赵波, 王秋 艳, 葛昌华, 李光风, 周仁贤. 催化学报), 2009, 30: 407

[2] Cui Y J, He Sh N, Fang R M, Shi Z H, Gong M C, Chen Y Q. Chin J Catal (崔亚娟, 何胜楠, 方瑞梅, 史忠华, 龚茂初, 陈耀强. 催化学报), 2012, 33: 1020

[3] Hungría A B, Calvino J J, Anderson J A, Martínez-Arias A. Appl Catal $B, 2006,62: 359$

[4] Lafyatis D S, Ansell G P, Bennett S C, Frost J C, Millington P J, Rajaram R R, Walker A P, Ballinger T H. Appl Catal B, 1998, 18: 123

[5] Zhu Z Z, Lu G Z, Guo Y, Guo Y L, Zhang Z G, Wang Y Q. J Ind Eng Chem, 2012, 18: 2135

[6] Cargnello M, Jaen J J D, Garrido J C H, Bakhmutsky K, Montini T, Gamez J J C, Gorte R J, Fornasiero P. Science, 2012, 337: 713

[7] Bounechada D, Groppi G, Forzatti P, Kallinen K, Kinnunen T. Appl Catal B, 2012, 119-120: 91

[8] Shan W P, Liu F D, He H, Shi X Y, Zhang C B. Chem Commun, 2011, 47: 8046

[9] Liu F D, Shan W P, Shi X Y, Zhang C B, He H. Chin J Catal (刘福东, 单文坡, 石晓燕, 张长斌, 贺泓. 催化学报), 2011, 32:1113

[10] Cao Y D, Ran R, Wu X D, Zhao B H, Wan J, Weng D. Appl Catal A, 


\title{
Graphical Abstract
}

Chin. J. Catal., 2014, 35: 1267-1280 doi: 10.1016/S1872-2067(14)60157-1

Effects of the addition of small quantities of ceria on the catalytic behavior of Pd-only close-coupled catalysts during automobile exhaust elimination

Xue Yang, Linyan Yang, Siyu Lin, Renxian Zhou*

Zhejiang University

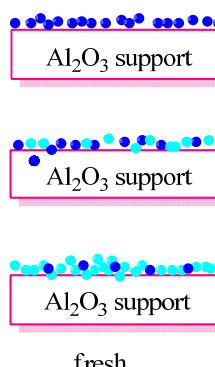

fresh

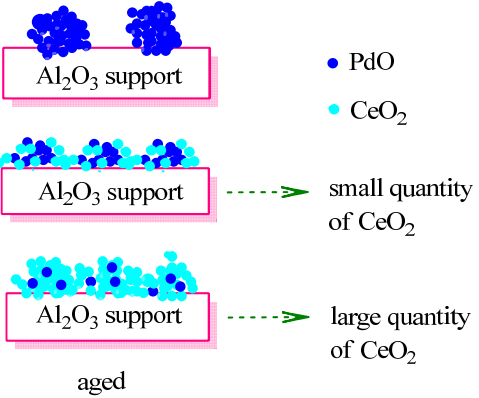

aged

The addition of an optimum concentration of ceria during the synthesis of Pd-only close-coupled catalysts by a co-adsorption impregnation method markedly improves the $\mathrm{HC} / \mathrm{NO}$ conversions and the thermal stability of the $\mathrm{Pd}-\mathrm{Ce} / \mathrm{La}-\mathrm{Al}_{2} \mathrm{O}_{3}$ catalyst.

2013, 457: 52

[11] Yan C Y, Lan L, Chen S H, Zhao M, Gong M C, Chen Y Q. Chin J Catal (闵朝阳, 兰丽, 陈山虎, 赵明, 龚茂初, 陈耀强. 催化学报), 2012, 33: 336

[12] Chen S H, Yao Y L, Lan L, Cao Y, Yan C Y, Gong M C, Chen Y Q. Chin J Catal (陈山虎, 姚艳玲, 兰丽, 曹毅, 间朝阳, 龚茂初, 陈耀强. 催 化学报), 2012, 33: 1762

[13] Colussi S, Gayen A, Farnesi Camellone M, Boaro M, Llorca J, Fabris S, Trovarelli A. Angew Chem Int Ed, 2009, 48: 8481

[14] Martinez-Arias A, Fernandez-Garcia M, Salamanca L N, Valenzuela R X, Conesa J C, Soria J.J Phy Chem B, 2000, 104: 4038

[15] Venâncio S A, de Miranda P E V. Ceram Int, 2011, 37: 3139

[16] Damyanova S, Perez C A, Schmal M, Bueno J M C. Appl Catal A, 2002, 234: 271

[17] Mira C, Calvino J J, Pérez-Omil J A, Rodríguez-Izquierdo J M, Bernal S. Catal Today, 2012, 180: 174

[18] Cargnello M, Wieder N L, Canton P, Montini T, Giambastiani G, Benedetti A, Gorte R J, Fornasiero P. Chem Mater, 2011, 23: 3961

[19] Cargnello M, Wieder N L, Montini T, Gorte R J, Fornasiero P. J Am Chem Soc, 2010,132: 1402

[20] Wang Y P, Zhao J S, Wang X L, Li Z, Liu P F. Bull Korean Chem Soc, 2013, 34: 2461

[21] Baylet A, Royer S, Marécot P, Tatibouët J M, Duprez D. Appl Catal B, 2008, 81: 88

[22] Li Y, Zhang X Y, Long E Y, Li H M, Wu D D, Cai L, Gong M C, Chen Y Q. J Nat Gas Chem, 2009, 18: 415

[23] Zhao B, Yang C Q, Wang Q Y, Li G F, Zhou R X.J Alloy Compd, 2010,
494: 340

[24] Wang J Q, Shen M Q, An Y, Wang J. Catal Commun, 2008, 10: 103

[25] Wang Q Y, Li G F, Zhao B, Zhou R X. Appl Catal B, 2010, 100: 516

[26] Osorio G P, Moyado S F, Petranovskii V, Simakov A. Catal lett, 2006, 110: 53

[27] Fernández-García M, Iglesias-Juez A, Martínez-Arias A, Hungría A B, Anderson J A, Conesa J C, Soria J. J Catal, 2004, 221: 594

[28] Gaudet J R, de la Riva A, Peterson E J, Bolin T, Datye A K. ACS Catal, 2013, 3: 846

[29] Yoshida H, Narisawa S, Fujita S, Ruixia L, Arai M. Phys Chem Chem Phys, 2012, 14: 4724

[30] Cárdenas-Lizana F, Gómez-Quero S, Hugon A, Delannoy L, Louis C, Keane M A. J Catal, 2009, 262: 235

[31] Alexeev O S, Krishnamoorthy S, Jensen C, Ziebarth M S, Yaluris G, Roberie T G, Amiridis M D. Catal Today, 2007, 127: 189

[32] Macleod N, Lambert R M. Appl Catal B, 2003, 46: 483

[33] Faria W L S, Perez C A C, César D V, Dieguez L C, Schmal M. Appl Catal B, 2009, 92: 217

[34] Baidya T, Bera P, Mukri B D, Parida S K, Kröcher O, Elsener M, Hegde M S. J Catal, 2013, 303: 117

[35] Hirano T, Ozawa Y, Sekido T, Ogino T, Miyao T, Naito S. Appl Catal A, 2007, 320: 91

[36] Oh H, Luo J Y, Epling W S. Catal Lett, 2011, 141: 1746

[37] Meunier F C, Zuzaniuk V, Breen J P, Olsson M, Ross J R H. Catal Today, 2000, 59: 287

[38] Abdulhamid H, Dawody J, Fridell E, Skoglundh M. J Catal, 2006, 244: 169

\section{少量 $\mathrm{CeO}_{2}$ 的添加对 $\mathrm{Pd} / \mathrm{La}-\mathrm{Al}_{2} \mathrm{O}_{3}$ 密偶催化剂三效性能的影响}

\author{
阳雪, 杨林颜, 林嗣煜, 周仁贤* \\ 浙江大学化学系催化研究所, 浙江杭州 310028
}

摘要: 以 $\mathrm{La}$ 改性的 $\mathrm{Al}_{2} \mathrm{O}_{3}$ 为载体, 采用共吸附浸渍法制备了一系列不同 $\mathrm{CeO}_{2}$ 含量的单 $\mathrm{Pd}$ 密偶催化剂, 并对其进行了表征. $\mathrm{PdO}$ 和 $\mathrm{CeO}_{2}$ 之间的强相互作用改善了 $\mathrm{Pd}^{0}$ 再氧化为 $\mathrm{PdO}$ 的能力, 同时增强了反应条件下硝酸盐, 亚硝酸盐和异氧酸盐在载体上的吸附. 因 
此适量 $\mathrm{CeO}_{2}$ 的添加明显改善了新鲜催化剂对 $\mathrm{HC}$ 和 $\mathrm{NO}_{x}$ 的催化性能, 且当 $\mathrm{CeO}_{2}$ 添加量为 $2 \%$ 时催化效果最佳. $\mathrm{Pd}-\mathrm{Ce}$ 界面上 $\mathrm{PdO}_{x}$ 和 $\mathrm{CeO}_{2}$ 间强相互作用也使得 $\mathrm{PdO}_{x}$ 物种在高温时仍能以小颗粒的形式分散在载体上, 从而显著地提高催化剂的热稳定性. 经 $1100{ }^{\circ} \mathrm{C}$ 高温老化后, $\mathrm{CeO}_{2}(2 \%-4 \%)$ 的存在明显拓宽了 $\mathrm{HC}$ 和 $\mathrm{NO}_{x}$ 的操作窗口, 这对于提高单Pd密偶催化剂在汽车尾气处理上的催化性能 有重要意义.

关键词：单钯密偶催化剂; 催化性能; 氧化铈; 热稳定性; 原位红外光谱

收稿日期: 2014-03-31. 接受日期: 2014-04-26. 出版日期: 2014-08-20.

*通讯联系人. 电话: (0571) 88273290; 传真: (0571) 88273283.; 电子信箱: zhourenxian@zju.edu.cn 基金来源：国家高技术研究发展计划(863计划, 2011AA03A406); 浙江省重点科技创新团队计划(2009R50020).

本文的英文电子版由Elsevier出版社在ScienceDirect上出版(http://www.sciencedirect.com/science/journal/18722067).

\section{1. 前言}

随着汽车尾气污染排放的日益增加, 各国相应的排 放法规也越来越严苛. 三效催化剂(TWC)是控制汽车尾 气污染物排放的主要技术 ${ }^{[1]}$. 目前投入商业应用的 TWC 包含了 $\mathrm{Pt} / \mathrm{Rh}, \mathrm{Pt} / \mathrm{Pd} / \mathrm{Rh}, \mathrm{Pd} / \mathrm{Rh}$ 和单 $\mathrm{Pd}$ 等贵金属催化剂 ${ }^{[2]}$. 单 $\mathrm{Pd}$ 三效催化剂因为其显著的氧化反应活性和价格低 廉等原因而广泛应用于汽车尾气的催化转化, 配置单Pd 三效催化剂的机动车数量也在增加 ${ }^{[3]}$. 汽车尾气中 $\mathrm{HC}$ 排放物的 $80 \%-90 \%$ 是在冷启动阶段生成的. 因此, 如果 $\mathrm{HC}$ 在冷启动阶段的排放量未得到有效控制, 那传统的 汽车将不能达到严格的排放标准 ${ }^{[4]}$. 目前提出了众多解 决冷启动问题的方案, 包括 $\mathrm{HC}$ 捕集器, 电加热催化剂, 燃烧加热催化剂, 废气点火, 微波加热和密偶催化剂 $(\mathrm{CCC})^{[5]}$. 其中, CCC因为不需要配置附加装置和额外 的能量输入而成为最直接有效的解决方法. CCC 非常靠 近汽车发动机, 以便快速地提高催化剂的温度. 然而, $\mathrm{CCC}$ 催化转化器在实际的三效催化转化过程中温度可 以达到 $1000{ }^{\circ} \mathrm{C}$ 以上, 导致 $\mathrm{Pd}$ 基催化剂在高温下烧结并 从氧化态转变为金属态 $\mathrm{Pd}$ 从而失活 ${ }^{[6]}$.

众所周知, $\mathrm{Ce}$ 通常被用作三效催化剂的助剂 ${ }^{[7-9]}$ 或 载体 ${ }^{[10-12]}$. 它由于具有在 $\mathrm{Ce}^{3+}$ 和 $\mathrm{Ce}^{4+}$ 之间灵活的转化能 力, 良好的热稳定性, 与贵金属的兼容性和容易浸渍到 氧化铝上等性能而被作为最主要的储氧材料 ${ }^{[2]}$. 另一方 面, $\mathrm{Pd}$ 嵌入到 $\mathrm{CeO}_{2}$ 晶格中会形成Pd-O-Ce键, 从而使 $\mathrm{Pd}$ 在载体表面高度分散 ${ }^{[13]}$. 当 $\mathrm{Ce}$ 含量小于 $10 \mathrm{wt} \%$ 时, $\mathrm{Ce}$ 可 以在氧化铝载体上以二维形式分布 ${ }^{[14]}$, 从而起到了联系 $\mathrm{Pd}$ 与 $\mathrm{Al}_{2} \mathrm{O}_{3}$ 的桥梁作用. 除此之外, 氧化条件下 $\mathrm{CeO}_{2}$ 和 $\mathrm{Al}_{2} \mathrm{O}_{3}$ 的强相互作用会使界面处生成 $\mathrm{CeAlO}_{3}$, 有助于 $\mathrm{Al}_{2} \mathrm{O}_{3}$ 表面的稳定 ${ }^{[15,16]}$. 然而, $\mathrm{Ce}$ 的添加量过大可能会对 贵金属颗粒形成包覆, 造成贵金属活性位点的不可逆流 失 ${ }^{[17]}$.

Cargnello 等 ${ }^{[6,18,19]}$ 利用颈基十一烷酸, 颈基壬醇和 十二硫醇制备了不同颈基保护的Pd纳米颗粒, 并将其与
$\mathrm{Ce}(\mathrm{IV})$ 醇盐反应生成 $\mathrm{Pd} @ \mathrm{CeO}_{2}$ 纳米颗粒. 但是这种方法 并不适用于商业应用, 而且 $\mathrm{Pd} @ \mathrm{CeO}_{2}$ 在高温下并不稳 定. Wang 等 ${ }^{[20]}$ 通过分布浸渍法制备了Pd-Ce催化剂: (1) 用 $\mathrm{PdCl}_{2}$ 的酸性水溶液作为前驱体将 $\mathrm{Pd}$ 浸渍在载体上; (2) $500{ }^{\circ} \mathrm{C}$ 炦烧后, 用同样的方法把 $\mathrm{Ce}\left(\mathrm{NO}_{3}\right)_{3}$ 的水溶液浸 渍在样品上. 但是在这种方法中, Ce在第一步中没有引 入. 本文使用共吸附浸渍法来形成Pd-Ce系统, 使Pd在初 始阶段就可以稀释在 $\mathrm{Ce}$ 中, 从而制备了一系列不同 $\mathrm{CeO}_{2}$ 含量的Pd-Ce密偶催化剂, 并测量其三效催化活性. 采用 $\mathrm{CO}$ 吸附, 高分辨透射电镜, $\mathrm{H}_{2}$-程序升温还原和原位红外 (in situ DRIFTS)等手段进行表征, 以期对 $\mathrm{PdO}_{x}$ 颗粒在载 体表面的状态和 $\mathrm{PdO}_{x}$ 与 $\mathrm{CeO}_{2}$ 之间的相互作用进行深入 研究.

\section{2. 实验部分}

\section{1. 催化剂制备}

$\mathrm{La}-\mathrm{Al}_{2} \mathrm{O}_{3}$ 载体购买自Rhodia公司. Pd-Ce密偶催化剂 在 $25^{\circ} \mathrm{C}$ 采用共吸附浸渍法来制备, $\mathrm{Pd}$ 含量为 $1 \mathrm{wt} \%$. $\mathrm{Pd}\left(\mathrm{NO}_{3}\right)_{2}$ 和 $\mathrm{Ce}\left(\mathrm{NO}_{3}\right)_{3}$ 的水溶液先混合摚拌 $20 \mathrm{~min}\left(\mathrm{CeO}_{2}\right.$ 含量分别为 $0,0.25,0.5,1.0,2.0$ 和 $4.0 \mathrm{wt} \%$ ), 然后把适量 的 $\mathrm{Al}_{2} \mathrm{O}_{3}$ 载体快速加入溶液中. 继续摚拌过夜后在 $110{ }^{\circ} \mathrm{C}$ 干燥, $500{ }^{\circ} \mathrm{C}$ 焙烧 $2 \mathrm{~h}$ 得到新鲜的催化剂样品, 分 别命名为 $\mathrm{Pd} / \mathrm{La}-\mathrm{A}$ 和 $\mathrm{Pd}-\mathrm{Ce}(x) / \mathrm{La}-\mathrm{A}(x=0.25,0.5,1.0,2.0$, 4.0). 最后取部分催化剂在 $1100{ }^{\circ} \mathrm{C}$ 焙烧 $4 \mathrm{~h}$ 来研究样品 的热稳定性. 老化后的样品分别命名为 $\mathrm{Pd} / \mathrm{La}-\mathrm{A}-\mathrm{a}$ 和 $\operatorname{Pd}-\mathrm{Ce}(x) / \mathrm{La}-\mathrm{A}-\mathrm{a}(x=0.25,0.5,1.0,2.0,4.0)$.

\section{2. 催化剂评价}

催化剂活性评价仪器为自建的微反装置, Bruker EQ55型傅立叶气体红外分析仪在线检测进出反应器气 体. 在石英管中填装 $0.2 \mathrm{~mL}$ 催化剂, 并在其两端填充石 英棉. 反应气的流量由质量流量控制器来控制, 其组成 为 $\mathrm{NO} 0.12 \%, \mathrm{NO}_{2} 0.03 \%, \mathrm{C}_{3} \mathrm{H}_{6} 0.066 \%, \mathrm{C}_{3} \mathrm{H}_{8} 0.033 \%$, $\mathrm{CO} 0.6 \%$ 和 $\mathrm{O}_{2} 0.745 \%$, 载气为 $\mathrm{Ar}$, 空速为 $43000 \mathrm{~h}^{-1}$ (计算 于催化剂的体积与室温下的气体流速). 虽然在反应过 
程中产生了少量的 $\mathrm{H}_{2} \mathrm{O}$, 但它的存在会损坏FTIR分光仪. 因此在气体进入仪器之前便除去了 $\mathrm{H}_{2} \mathrm{O}$, 它的浓度也没 有列于图表中.

空燃比定义为 $\lambda=\left(2 V_{\mathrm{O} 2}+V_{\mathrm{NO}}+2 V_{\mathrm{NO} 2}\right) /\left(V_{\mathrm{CO}}+\right.$ $\left.9 V_{\mathrm{C} 3 \mathrm{H} 6}+10 V_{\mathrm{C} 3 \mathrm{H} 8}\right)$, 其中 $V$ 代表各气体组分的体积百分含 量, $\lambda=1$ 应用于所有的活性评价中. 催化剂窗口测试在 $400{ }^{\circ} \mathrm{C}$ 下进行, 通过调节氧含量来设置不同的 $\lambda$ 值.

\section{3. 催化剂表征}

$\mathrm{H}_{2}$-TPR实验在GC-1690型色谱分析仪上进行. 将50 $\mathrm{mg}$ 催化剂在 $\mathrm{N}_{2}$ 气氛下 $(30 \mathrm{ml} / \mathrm{min}) 200{ }^{\circ} \mathrm{C}$ 处理 $30 \mathrm{~min}$, 用 液氮冷却至 $-90{ }^{\circ} \mathrm{C}$ 后, 通入 $5 \mathrm{vol} \% \mathrm{H}_{2} / \mathrm{Ar}(40 \mathrm{ml} / \mathrm{min})$ 至 基线稳定, 再以 $10^{\circ} \mathrm{C} / \mathrm{min}$ 升温至 $900{ }^{\circ} \mathrm{C}$. 还原过程中消 耗的氢气通过热导检测器(TCD)进行检测.

$\mathrm{CO}$ 吸附在室温下由 CHEMBET-3000 型 (Quantachrome公司)化学吸附仪进行检测, 以此计算Pd 的分散度和颗粒尺寸. 实验前, 样品在 $5 \% \mathrm{H}_{2}-95 \% \mathrm{~N}_{2}$ 气 氛中 $400{ }^{\circ} \mathrm{C}$ 还原 $1 \mathrm{~h}$, 在 $\mathrm{He}$ 中保持 $30 \mathrm{~min}$ 后, 样品在 $\mathrm{He}$ 中 冷却至室温并保持 $30 \mathrm{~min}$. 最后, $\mathrm{CO}$ 每隔 $5 \mathrm{~min}$ 脉冲入样 品中直到没有检测到 $\mathrm{CO}$ 的消耗为止. $\mathrm{Pd}$ 的分散度 $(D)$ 计 算如下 ${ }^{[21]}$ :

$$
D(\%)=100 \times\left[(V \mathrm{co} \times f) /\left(C_{\mathrm{Pd}} \times m_{\text {Cat. }} \times 22414\right)\right] \times m
$$

$V \mathrm{co}, \mathrm{CO}$ 吸附的体积 $(\mathrm{mL}) ; f$, 化学计量数; $C_{\mathrm{Pd}}$, 金属Pd的 含量 $(\mathrm{wt} \%) ; m_{\text {Cat. }}$, 催化剂的质量 $(\mathrm{g})$. Pd颗粒尺寸(d)计算 如下:

$$
d(\mathrm{~nm})=6 \times 10^{5} \times M_{\mathrm{Pd}} /\left(\rho_{\mathrm{Pd}} \times D \times S_{\mathrm{Pd}}\right)
$$

$M_{\mathrm{Pd}}, \mathrm{Pd}$ 的摩尔质量 $(106.42 \mathrm{~g} / \mathrm{mol}) ; \rho_{\mathrm{Pd}}, \mathrm{Pd}$ 的密度 $(12$ $\left.\mathrm{g} / \mathrm{cm}^{3}\right) ; S_{\mathrm{Pd}}$, Pd的摩尔表面积 $\left(S=47780 \mathrm{~m}^{2} / \mathrm{mol}\right)$.

HRTEM照片由TECNAI G220型透射电镜表征获 得, 工作电压为 $200 \mathrm{kV}$. 催化剂首先在研钵中碾碎, 无水 乙醇中超声分散后担载在镀有碳膜的铜网上. EDS分析 用来记录元素分布, 从而得到化学组成.

原位漫反射红外傅立叶变换光谱测试 (In situ DRIFTS)在配置了MCT (merbury-cadnium-tellvride)检测 器的 Nicolet 6700 FTIR 分光仪上进行. 原位池窗片为 $\mathrm{CaF}_{2}$, 有一个可加热的反应室来进行高温反应, 扫描次 数 32 , 分辨率 $4 \mathrm{~cm}^{-1}$. 催化剂在 $\mathrm{Ar}$ 中 $450{ }^{\circ} \mathrm{C}$ 下预处理 30 $\min$, 然后冷却至 $30^{\circ} \mathrm{C}$. 反应器的组成和流速在反应过 程中保持稳定.

\section{3. 结果与讨论}

\section{1. 催化剂的活性评价}

图1给出了模拟汽车尾气气氛下 $(\lambda=1)$ 新鲜 $\mathrm{Pd} / \mathrm{La}-\mathrm{A}$
和 $\mathrm{Pd}-\mathrm{Ce}(x) / \mathrm{La}-\mathrm{A}$ 催化剂上 $\mathrm{HC}, \mathrm{CO}, \mathrm{NO}$ 和 $\mathrm{NO}_{2}$ 的转化率. 由图1可见, 在 $150-200{ }^{\circ} \mathrm{C}$ 温度范围, $\mathrm{HC}$ 和 $\mathrm{NO}$ 并未参与 反应, 而 $\mathrm{CO}+1 / 2 \mathrm{O}_{2} \rightarrow \mathrm{CO}_{2}$ 和 $2 \mathrm{NO}_{2}+4 \mathrm{CO} \rightarrow \mathrm{N}_{2}+4 \mathrm{CO}_{2}$ 在反应中占主导地位. $\mathrm{CO}$ 和 $\mathrm{NO}_{2}$ 的起燃温度随着 $\mathrm{CeO}_{2}$ 添加量的增加而增高, 说明当温度低于 $200{ }^{\circ} \mathrm{C}$ 时, $\mathrm{CeO}_{2}$ 的添加抑制了 $\mathrm{CO}$ 和 $\mathrm{NO}_{2}$ 的转化. 在 $200-250{ }^{\circ} \mathrm{C}$ 的温度范 围, $\mathrm{CO} / \mathrm{O}_{2}$ 和 $\mathrm{NO}_{2} / \mathrm{CO}$ 反应仍然是主要的. 各催化剂上 $\mathrm{CO}$ 转化率均达到 $100 \%$, 而 $\mathrm{NO}_{2}$ 的转化率却随着温度的增加 而降低, 可能是由于 $\mathrm{CO} / \mathrm{O}_{2}$ 反应比 $\mathrm{NO}_{2} / \mathrm{CO}$ 反应进行得更 快. 不同的是, 在 $200-250{ }^{\circ} \mathrm{C}$ 温度范围中各催化剂上 $\mathrm{NO}_{2}$ 转化率随 $\mathrm{CeO}_{2}$ 添加量的增加而增大, 其中 $\mathrm{Pd}-\mathrm{Ce}(2.0) / \mathrm{La}-\mathrm{A}$ 表现出最好的 $\mathrm{NO}_{2}$ 还原的活性.

当温度大于 $250{ }^{\circ} \mathrm{C}$ 时, $\mathrm{HC}, \mathrm{NO}$ 和 $\mathrm{NO}_{2}$ 的转化率随温 度增加而增大, $\mathrm{HC}$ 与 $\mathrm{NO}$ 转化曲线一致. 研究发现 ${ }^{[22]}$, $\mathrm{NO}_{x}$ 的转化由 $10 \mathrm{NO}+4 \mathrm{HC} \rightarrow 5 \mathrm{~N}_{2}+4 \mathrm{CO}_{2}+2 \mathrm{H}_{2} \mathrm{O}$ 和 $10 \mathrm{NO}_{2}+8 \mathrm{HC} \rightarrow 5 \mathrm{~N}_{2}+4 \mathrm{CO}_{2}+4 \mathrm{H}_{2} \mathrm{O}$ 两个反应来控制. 以上结果表明, 适量 $\mathrm{CeO}_{2}$ 的添加可以提高 $\mathrm{HC}$ 和 $\mathrm{NO}_{x}$ 的反 应活性. 随着 $\mathrm{CeO}_{2}$ 添加量从 0.25 增加到 $2.0 \mathrm{wt} \%$, 催化活 性明显增强, 至 $4.0 \mathrm{wt} \%$ 时活性急剧下降. 其中 Pd-Ce(2.0)/La-A表现出最好的催化活性.

图2为模拟汽车尾气气氛下 $(\lambda=1)$ 老化后的 $\mathrm{Pd} / \mathrm{La}-\mathrm{A}$ 和Pd-Ce $(x) / \mathrm{La}-\mathrm{A}$ 催化剂上 $\mathrm{HC}, \mathrm{CO}, \mathrm{NO}$ 和 $\mathrm{NO}_{2}$ 的转化率. 与图1相比, 老化后催化剂的活性大大减弱, 这与催化剂 在高温处理后 $\left(1100{ }^{\circ} \mathrm{C}\right)$ 导致的活性组分烧结和载体结 构塌陷有关 ${ }^{[23]}$. 尽管如此, 催化剂的活性仍随着 $\mathrm{CeO}_{2}$ 添 加量的增加而增强, 其中Pd-Ce(4.0)/La-A-a 呈现出最好 的 CO 和 $\mathrm{HC}$ 的氧化活性, 而Pd-Ce(2.0)/La-A-a催化NO和 $\mathrm{NO}_{2}$ 还原活性最高. 这说明适量 $\mathrm{CeO}_{2}$ 的添加会在不包覆 $\mathrm{PdO}_{x}$ 物种的情况下提高催化剂的热稳定性, 这对改善密 偶催化剂的活性有重要意义.

本文还评估了 $400{ }^{\circ} \mathrm{C}$ 时不同空燃比窗口下 $\mathrm{CO}, \mathrm{HC}$ 和 $\mathrm{NO}_{x}$ 在新鲜和老化催化剂上的转化. 对于所有的新鲜 催化剂(数据未列出), $\mathrm{CO}, \mathrm{HC}$ 和 $\mathrm{NO}_{x}$ 的转化率并没有明 显差异. $\mathrm{HC}$ 均为 $100 \%$ 转化, $\mathrm{CO}$ 的转化率在整个 $\lambda$ 范围都 高于 $80 \%, \mathrm{NO}_{x}$ 的转化率也只有轻微的区别. 然而, 在 $1100{ }^{\circ} \mathrm{C}$ 老化之后, 各催化剂的催化行为变化显著. 如图 3 所示, 在贫氧条件下 $(\lambda<1), \mathrm{CO}$ 的转化率随着 $\mathrm{CeO}_{2}$ 添加 量的增加而有所下降. Pd/La-A-a上HC转化率在整个窗 口中都低于 $80 \%$, 这可能是因为 $\mathrm{PdO}$ 在老化过程中还原 为 $\mathrm{Pd}^{0}$ 而导致 $\mathrm{HC}$ 氧化活性的降低 ${ }^{[24]}$. 当 $\lambda>0.95$ 时, $\mathrm{Pd} / \mathrm{La}-\mathrm{A}-\mathrm{a}$ 的 $\mathrm{NO}_{x}$ 转化率急剧减少. 由此可见, $1100{ }^{\circ} \mathrm{C}$ 的 高温老化明显破坏了 $\mathrm{Pd} / \mathrm{La}-\mathrm{A}-\mathrm{a}$ 的操作窗口. 但是, $\mathrm{CeO}_{2}$ 
的添加拓宽了催化剂的操作窗口, $\mathrm{HC}$ 和 $\mathrm{NO}_{x}$ 的转化率也 随着 $\mathrm{CeO}_{2}$ 添加量的增加而明显增大, 这表明 $\mathrm{PdO}_{x}$ 和 $\mathrm{CeO}_{2}$ 间的相互作用可以使 $\mathrm{PdO}_{x}$ 物种稳定在氧化态. $\mathrm{Pd}-\mathrm{Ce}(4.0) / \mathrm{La}-\mathrm{A}-\mathrm{a}$ 有最宽的 HC 窗口, 而 Pd-Ce(2.0)/ $\mathrm{La}-\mathrm{A}-\mathrm{a}$ 有最宽的 $\mathrm{NO}_{x}$ 窗口. 为得到关于 $\mathrm{PdO}_{x}$ 物种在载体 表面的构型和 $\mathrm{PdO}_{x}$ 与 $\mathrm{CeO}_{2}$ 间相互作用的信息, 对催化剂 进行了CO吸附, HRTEM, $\mathrm{H}_{2}$-TPR 和原位红外等表征.

\section{2. 结构特性}

各催化剂的 $\mathrm{Pd}$ 分散度及其颗粒尺寸列于表1. 对所 有新鲜催化剂来说, $\mathrm{Pd}$ 在载体表面分散度都较高, Pd颗 粒尺寸随着 $\mathrm{CeO}_{2}$ 含量的增加而略有增大. 反之, 催化剂 老化后Pd的颗粒尺寸随着 $\mathrm{CeO}_{2}$ 含量的增加而减小, 说明 $\mathrm{CeO}_{2}$ 的添加可以增强 $\mathrm{PdO}_{x}$ 物种的高温稳定性并减缓烧 结的过程, 这可以与催化剂的活性变化趋势相关联. 含 $2 \% \mathrm{CeO}_{2}$ 的催化剂在 $1100{ }^{\circ} \mathrm{C}$ 老化后呈现出最高的 $\mathrm{Pd}$ 分 散度和最小的 $\mathrm{Pd}$ 颗粒尺寸.

如表1所示, 金属Pd颗粒尺寸的理论值与 $\mathrm{PdO}_{x}$ 颗粒 的实际大小并不相同. 为了从原子尺度来研究 $\mathrm{Pd} / \mathrm{La}-\mathrm{A}$ 和Pd-Ce(2.0)/La-A结构上的不同, 我们对催化剂进行了 $\mathrm{TEM}$ 表征. 如图4所示, 新鲜催化剂上只能观测到 $\mathrm{La}_{2} \mathrm{O}_{3}$ $(0.307 \mathrm{~nm})$ 和 $\mathrm{CeO}_{2}(0.312 \mathrm{~nm})$ 的晶面间距. 由于 $\mathrm{PdO}_{x}$ 颗 粒含量低, 分散度高以及小的Pd族不易与载体区分等原 因而无法在图中找到. 然而对 Pd-Ce(2.0)/La-A进行的 EDS线扫描分析显示(图4(c)和(d)), 图中的白点由Pd和 $\mathrm{Ce}$ 共同组成, 清晰地指出了 Pd-Ce结构的存在.

图 5 是老化催化剂的TEM照片. Pd-Ce(2.0)/La-A 上 也能观察到 $\mathrm{PdO}$ 的 (101) 晶面 $(d=0.262 \mathrm{~nm})$ 和 $\mathrm{Ce}_{2} \mathrm{O}_{3}$ 的 (011) 晶面 $(d=0.298 \mathrm{~nm})$. 如图 5(a) 和 (c) 所示, 老化后 $\mathrm{PdO}$ 的颗粒尺寸因烧结作用而急剧增大. 但 $\mathrm{Pd}-\mathrm{Ce}(2.0) / \mathrm{La}-\mathrm{A}-\mathrm{a}$ 中的 Pd-Ce复合氧化物颗粒尺寸 $(20-50 \mathrm{~nm})$ 明显比 $\mathrm{Pd} / \mathrm{La}-\mathrm{A}-\mathrm{a}$ 的 PdO 颗粒尺寸 $(70 \mathrm{~nm})$ 更 小, 这与表 1 结果一致, 证明 $\mathrm{CeO}_{2}$ 的添加有助于稳定 $\mathrm{PdO}_{x}$ 物种的颗粒尺寸. 这可能是Pd-Ce(2.0)/La-A-a在老化后 也能保持良好的催化活性的主要原因.

\section{3. $\mathrm{H}_{2}$-TPR结果}

图6为新鲜和老化后催化剂的 $\mathrm{H}_{2}$-TPR谱. 新鲜催化 剂在 $400{ }^{\circ} \mathrm{C}$ 以下出现了四个峰 $(\alpha, \beta, \gamma$ 和 $\delta)$ 以及一个负峰. $\alpha$ 峰可归属于高度分散在载体上 $\mathrm{PdO}_{x}$ 物种的还原, $70{ }^{\circ} \mathrm{C}$ 左右的负峰则对应于氢化钯的分解 ${ }^{[25]}$. 其中, 氢化钯是 由 $\mathrm{PdO}$ 还原生成的金属 $\mathrm{Pd}$ 与 $\mathrm{H}_{2}$ 进一步作用所形成 ${ }^{[10,23]}$. 当催化剂中 $\mathrm{CeO}_{2}$ 的添加量达到 $0.5 \mathrm{wt} \%$ 时, 负峰消失. 随 着 $\mathrm{CeO}_{2}$ 的添加量进一步增加, $\beta$ 峰开始出现. 此外, $\alpha$ 峰
逐渐往高温偏移. Osorio等 ${ }^{[26]}$ 发现, $\mathrm{Ce}_{x} \mathrm{Zr}_{1-x} \mathrm{O}_{2}$ 复合氧化 物的添加在可促进 $\mathrm{Pd}$ 与 $\mathrm{Al}_{2} \mathrm{O}_{3}$ 间相互作用, 当 $x=0.5$ 和 0.33 时, 会有部分难以被还原的 $\mathrm{PdO}$ 物种形成. 因此我们 推测 $\alpha$ 峰往高温迁移与 $\mathrm{Pd}$ 和载体间相互作用增强有关, 而 $\beta$ 峰也可归属于与 $\mathrm{CeO}_{2}$ 有强相互作用的 $\mathrm{PdO}_{x}$ 物种的还 原. 对所有新鲜催化剂来说, $\gamma$ 和 $\delta$ 峰的强度与峰温都没 有明显的区别, 表明这两个峰的出现可能与 La改性的 $\mathrm{Al}_{2} \mathrm{O}_{3}$ 载体的还原有关. 研究发现 ${ }^{[27]}, \mathrm{Pd}$ 和 $\mathrm{CeO}_{2}$ 的相互 作用可以使 $\mathrm{Pd}$ 簇稳定在 $\mathrm{Pd}^{+}$氧化态, 而 $\mathrm{Pd}^{+}$的存在可以有 效地降低HC和NO的起燃温度(如图1). 除此之外, $\alpha$ 峰与 $\beta$ 峰往高温偏移说明 $\mathrm{Pd}$ 和 $\mathrm{CeO}_{2}$ 的相互作用逐渐增强, 这 也许是低温下 $\mathrm{CO}$ 和 $\mathrm{NO}_{2}$ 转化率随着 $\mathrm{CeO}_{2}$ 的添加而减少 的原因.

$1100{ }^{\circ} \mathrm{C}$ 老化后, 催化剂的高温烧结造成活性 $\mathrm{PdO}_{x}$ 物种分散度降低, 使得 $\alpha$ 峰与 $\beta$ 峰的耗氢量减少. $\mathrm{PdO}_{x}$ 物 种的烧结造成 $\mathrm{PdO}_{x}$ 与载体的相互作用减弱, 因此与新鲜 催化剂相比, $\alpha$ 峰与 $\beta$ 峰均移向较低温度. 但是在老化催 化剂中, $\mathrm{Pd}$ 和 $\mathrm{CeO}_{2}$ 的强相互作用仍然导致了 $\alpha$ 峰与 $\beta$ 峰随 着 $\mathrm{CeO}_{2}$ 的添加往高温偏移.

\subsection{In situ DRIFTS结果}

为了观察在催化反应中特定 $\mathrm{Pd}$ 物相的存在与催化 反应之间的联系, 我们在不同反应条件下对催化剂进行 了原位红外表征. 图 7(a)和(b)为 $250{ }^{\circ} \mathrm{C}$ 时新鲜催化剂 $\mathrm{Pd} / \mathrm{La}-\mathrm{A}$ 和 $\mathrm{Pd}-\mathrm{Ce}(2.0) / \mathrm{La}-\mathrm{A}$ 在 $\mathrm{CO}+\mathrm{HC}+\mathrm{O}_{2}$ 气氛下采集 的谱图. 1800-2100 $\mathrm{cm}^{-1}$ 之间出现的峰归属于羰基物种 在 $\mathrm{Pd}^{0}$ 上的吸附. 其中 $2063 \mathrm{~cm}^{-1}$ 是线式吸附 $\mathrm{Pd}-\mathrm{CO}, 1972$ $\mathrm{cm}^{-1}$ 是桥式吸附 $\mathrm{Pd}_{2}-\mathrm{CO}, 1909 \mathrm{~cm}^{-1}$ 是三原子协同吸附 $\mathrm{Pd}_{3}-\mathrm{CO}^{[28,29]}$, 说明部分 $\mathrm{PdO}_{x}$ 物种在反应条件下会部分还 原为金属态的 $\mathrm{Pd} . \mathrm{Pd} / \mathrm{La}-\mathrm{A}$ 上这三种吸附峰强度明显大 于在 $\mathrm{Pd}-\mathrm{Ce}(2.0) / \mathrm{La}-\mathrm{A}$ 上的峰强, 表明 $\mathrm{Pd}-\mathrm{Ce}(2.0) / \mathrm{La}-\mathrm{A}$ 被 还原的金属 $\mathrm{Pd}$ 较少 ${ }^{[28]}$, 这说明少量 $\mathrm{CeO}_{2}$ 的存在能促进反 应条件下 $\mathrm{Pd}^{0}$ 再氧化为 $\mathrm{PdO}$ 的过程. 此外, 我们很难在 $\mathrm{Pd}-\mathrm{Ce}(2.0) / \mathrm{La}-\mathrm{A}$ 上看到 $\mathrm{Pd}_{3}-\mathrm{CO}$ 吸附物种, 同时桥式吸附 与线式吸附的峰也往低波数偏移. 从文献 [30]类推, $\mathrm{Pd}-\mathrm{Ce}$ 复合氧化物纳米颗粒的形成使得 $\mathrm{Pd}$ 可以在 $\mathrm{CeO}_{2}$ 中 稀释, 从而限制了 $\mathrm{Pd}_{2}-\mathrm{CO}$ 的形成并导致 $\mathrm{Pd}_{3}-\mathrm{CO}$ 的消失. 1200-1800 cm $\mathrm{cm}^{-1}$ 之间的峰归属于在 $\mathrm{Al}_{2} \mathrm{O}_{3}$ 表面吸附的碳 酸盐与羧酸盐物种 ${ }^{[31,32]}$. 这些物种的吸附峰强度随着时 间的增加并没有明显的变化, 可能是因为催化剂在 $250{ }^{\circ} \mathrm{C}$ 刚暴露于 $\mathrm{CO}+\mathrm{HC}+\mathrm{O}_{2}$ 气氛中时, 碳酸盐与羧酸 盐物种在 $\mathrm{Al}_{2} \mathrm{O}_{3}$ 表面的吸附就几乎达到最大值. 这可能 与 $\mathrm{CO}$ 在该温度下已经完全转化有关. 
催化剂暴露在 $\mathrm{CO}+\mathrm{HC}+\mathrm{O}_{2}$ 气氛中 $10 \mathrm{~min}$ 后, 化学 计量的 $\mathrm{NO}_{x}$ 也快速加入了反应气氛中. 如图7(c)和(d) 所 示, 2253 与 $2231 \mathrm{~cm}^{-1}$ 处的吸收峰分别代表 $\mathrm{NCO}$ 在八面体 的 $\mathrm{Al}^{3+}$ 与四面体的 $\mathrm{Al}^{3+}$ 上的峰 ${ }^{[33]}$. $\mathrm{NCO}$ 物种是由吸附的 $\mathrm{N}$ 原子与未反应的 $\mathrm{CO}$ 相互作用而形成 ${ }^{[34]}$. $\mathrm{N}_{\mathrm{a}}$ 的形成有两 种机理: (1) 由 $\mathrm{NO}$ 的单分子解离吸附形成 $\mathrm{N}_{\mathrm{a}}$ 和 $\mathrm{O}_{\mathrm{a}}$; (2) 由 $\mathrm{NO}$ 与 $\mathrm{CO}$ 的双分子反应形成 $\mathrm{N}_{\mathrm{a}}$ 和 $\mathrm{CO}_{2}{ }^{[35]}$. $\mathrm{NCO}$ 的出现时 机和峰强可以对 $\mathrm{NO}$ 分解的起燃温度作粗略考量. 两种 $\mathrm{NCO}$ 吸附峰的峰强在第 $2 \mathrm{~min}$ 时就达到最大值, 然后随 着反应 $\mathrm{NCO}+\mathrm{NO}+\mathrm{O}_{2} \rightarrow \mathrm{N}_{2}$ 的出现而逐渐减弱. 值得 注意的是, $\mathrm{Pd}-\mathrm{Ce}(2.0) / \mathrm{La}-\mathrm{A}$ 上 $\mathrm{NCO}$ 的吸附峰远远强于在 $\mathrm{Pd} / \mathrm{La}-\mathrm{A}$ 上的, 表明 $\mathrm{Pd}-\mathrm{Ce}(2.0) / \mathrm{La}-\mathrm{A}$ 上形成了更多的 $\mathrm{NCO}$ 物种, 从而更有利于 $\mathrm{NO}_{x}$ 在 $250^{\circ} \mathrm{C}$ 的转化, 这与催化 活性的数据一致(图1). Pd-Ce(2.0)/La-A在 $2175 \mathrm{~cm}^{-1}$ 处出 现一个新峰. 由 $\mathrm{H}_{2}-\mathrm{TPR}$ 结果可知催化剂中有两种不同 的 $\mathrm{PdO}_{x}$ 物种, 而 $2175 \mathrm{~cm}^{-1}$ 处的峰可能是 $\mathrm{NCO}$ 吸附在与 $\mathrm{CeO}_{2}$ 有强相互作用的 $\mathrm{Pd}^{0}$ 上所致. 与此同时, 在 1610 , 1575 和 $1459 \mathrm{~cm}^{-1}$ 处也出现了三个峰, 并且在第 $5 \mathrm{~min}$ 达 到最大峰强. 其中 $1610 \mathrm{~cm}^{-1}$ 归属于双配位的硝酸盐物 种, 1575 和 $1459 \mathrm{~cm}^{-1}$ 归属于表面硝酸盐物种与 $\mathrm{HC}$ 反应 形成的醋酸盐 ${ }^{[36]}$. Pd-Ce(2.0)/ $\mathrm{La}-\mathrm{A}$ 上硝酸盐和醋酸盐的 吸附峰强度也大于在 $\mathrm{Pd} / \mathrm{La}-\mathrm{A}$ 上的峰强, 这与前者有更 好的 $\mathrm{NO} / \mathrm{HC}$ 催化活性相关. 此外, 与图 7(a)和 (b)相比, $\mathrm{CO}$ 在 $\mathrm{Pd}^{0}$ 上的吸附峰强度在通入 $\mathrm{NO}_{x}$ 后变弱, 说明具有 强氧化性的 $\mathrm{NO}_{2}$ 的存在有助于稳定氧化钯物种, 特别是 小的 $\mathrm{Pd}$ 簇.

为了阐明催化剂的反应机理, 新鲜催化剂在汽车尾 气气氛中从 50 到 $400{ }^{\circ} \mathrm{C}$ 进行了一系列原位红外的表征. 如图 8所示, $50{ }^{\circ} \mathrm{C}$ 时可以观测到在 $1200-1800 \mathrm{~cm}^{-1}$ 出现 三个主要的吸附峰, 归属于在 $\mathrm{Al}_{2} \mathrm{O}_{3}$ 上形成的结构各不 相同的亚硝酸盐/硝酸盐 ${ }^{[37,38]}$. Pd-Ce(2.0)/La-A 上这三个 峰的强度明显强于 $\mathrm{Pd} / \mathrm{La}-\mathrm{A}$, 并且在 $50^{\circ} \mathrm{C}$ 时就几乎达到 最大峰强. 说明 $\mathrm{CeO}_{2}$ 的添加更利于载体对亚硝酸盐/硝
酸盐的吸附, 进而有利于 $\mathrm{NO}$ 在低温下的转化. 这些峰随 着温度的升高而减弱. 温度的升高使 $\mathrm{CO}-\mathrm{NO}_{x}$ 活性增强, $\mathrm{NO}_{x}$ 的脱附也增多, 这使得 $\mathrm{NO}_{x}$ 在催化剂表面的吸附量 减少, 因而单齿配位的亚硝酸盐物种 $\left(1319 \mathrm{~cm}^{-1}\right)^{[37]}$ 随着 温度的升高逐渐迁移向低波数并且在 $270{ }^{\circ} \mathrm{C}$ 消失. 亚硝 酸盐物种消失的同时, NCO物种的吸附峰(2100-2300 $\mathrm{cm}^{-1}$ )和醋酸盐与硝酸盐的吸附峰(1400-1800 $\mathrm{cm}^{-1}$ )开始 出现, 并且随着温度的升高而增强. 如前所述, 这些峰的 变化与 $\mathrm{HC}$ 和 $\mathrm{NO}_{x}$ 的催化活性相关. 与 $\mathrm{Pd} / \mathrm{La}-\mathrm{A}$ 相比, Pd-Ce(2.0)/La-A上这些峰出现的温度更低, 峰更强, 表明 其催化 $\mathrm{HC} / \mathrm{NO}_{x}$ 反应的活性更高. $\mathrm{Pd} / \mathrm{La}-\mathrm{A}$ 上, 三个归属 于 $\mathrm{CO}$ 在 $\mathrm{Pd}^{0}$ 上吸附的峰 $\left(2061,1972\right.$ 和 $\left.1911 \mathrm{~cm}^{-1}\right)$ 出现于 $190{ }^{\circ} \mathrm{C}$, 说明反应气氛中部分 $\mathrm{PdO}_{x}$ 物种被还原为金属态 $\mathrm{Pd}$. 然而在 $\mathrm{Pd}-\mathrm{Ce}(2.0) / \mathrm{La}-\mathrm{A}$ 上几乎不能检测到 $\mathrm{CO}$ 的吸 附峰, 说明 $\mathrm{CeO}_{2}$ 的添加有利于 $\mathrm{PdO}_{x}$ 物种的稳定.

\section{4. 结论}

以 $\mathrm{La}-\mathrm{Al}_{2} \mathrm{O}_{3}$ 为载体, 采用共吸附浸渍法制备了一系 列不同 $\mathrm{CeO}_{2}$ 含量的单Pd密偶催化剂. 结果表明, $\mathrm{CeO}_{2}$ 的 添加明显提高了催化剂对 $\mathrm{HC}$ 和 $\mathrm{NO}$ 的催化活性. 这是由 于 $\mathrm{PdO}_{x}$ 和 $\mathrm{CeO}_{2}$ 间的强相互作用改善了 $\mathrm{Pd}^{0}$ 再氧化为 $\mathrm{PdO}$ 的能力, 同时增强了反应条件下硝酸盐, 亚硝酸盐和异 氧酸盐在载体上的吸附. Pd- $\mathrm{Ce}(2.0) / \mathrm{La}-\mathrm{A}$ 呈现了最好的 $\mathrm{HC}$ 和 $\mathrm{NO}_{x}$ 的催化活性. 然而 $\mathrm{CeO}_{2}$ 的添加抑制了 $\mathrm{CO}$ 和 $\mathrm{NO}_{2}$ 的转化. Pd-Ce(4.0)/La-A对 CO, $\mathrm{HC}$ 和 $\mathrm{NO}_{x}$ 的催化活 性均为最差, 这可能是由于过量的 $\mathrm{CeO}_{2}$ 会对 $\mathrm{Pd}$ 形成包 覆, 从而抑制了其催化性能. 然而, 老化后的催化剂中, 适量的 $\mathrm{CeO}_{2}(2 \%-4 \%)$ 的添加明显拓宽了 $\mathrm{HC}$ 和 $\mathrm{NO}_{x}$ 的操 作窗口. 同时, $\mathrm{CeO}_{2}$ 的添加明显提高了催化剂对三种反 应物的催化活性. 这是因为 $\mathrm{Pd}-\mathrm{Ce}$ 界面上 $\mathrm{PdO}_{x}$ 和 $\mathrm{CeO}_{2}$ 间 的强相互作用使得 $\mathrm{PdO}_{x}$ 物种在 $1100{ }^{\circ} \mathrm{C}$ 高温老化后仍能 以小颗粒的形式分散在载体上, 从而显著地提高催化剂 的热稳定性. 